\title{
Chinese Narratives of "National Humiliation" and Japan's Role in the Construction of China's National Identity, 1915 to the early 2000 s
}

\author{
By \\ Boyang Li
}

\begin{abstract}
A thesis
submitted to the Victoria University of Wellington in fulfillment of the requirements for the degree of Master of International Relations in International Relations
\end{abstract}

Victoria University of Wellington 
Introduction.

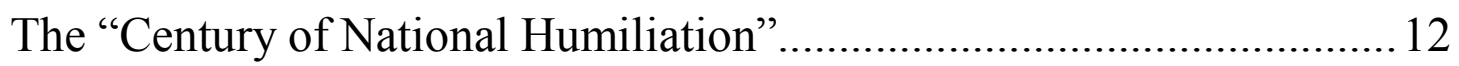

Victim Narrative in the Pre-1949 Era......................................................15

The origin of humiliation narrative during Beiyang government (1912-1927)................... 16

"National humiliation" in Kuomin Party (KMT) government and Japan as a "national enemy"(1927-1948)....... .19

The Absence of Victim Narrative in China's Civil Society (1950s-1980s) 26

Victor discourse in the Maoist era and Japan as a "friend" (1949-the late 1970s)............26

A pragmatic China and Japan as a "partner" (1970s-1980s). .34

The Revival of Victim Discourse since the Late-1980s.

"Patriotic Education Campaign" and a changing image of Japan (since the early 1990s)44

Influence of the new wave of victim discourse on Chinese society...... .51

Conclusion. .58

References. 62 


\section{Abstract}

The sense of national humiliation in China derives from a huge psychological gap between a glorious Empire and a peripheral nation-state which invaded by foreign imperialists in the $19^{\text {th }}$ century and the early $20^{\text {th }}$ century. This gap let Chinese people tend to define the period from $1840 \mathrm{~s}$ to $1940 \mathrm{~s}$ as the "Century of National Humiliation". Although, Chinese people suffer a lot during this "Century", direct experience and the meaning attached it are not the same. Apart from history itself, this thesis argues that narratives of naitoanal humiliation are significant in constructing China's national identity. In this sense, it will focus on China's humiliation narratives in different periods, and try to find out what kind of role Japan plays in the construction of China's national identity. In the first place, this thesis will focus on the narratives of humiliation/victim in different periods of China since its popularization in 1915, and try to give a comprehensive picture of the origin and evolution of this narrative. More specifically, it will examine Chinese humiliation narratives in the following three main periods chronologically: the origins and evolution of "national humiliation" in the pre-1949 era, the absense of "national humiliation" from the 1950s to the 1980s, and the reinvention of "national humiliation" in the post-1989 era. It argues that the narratives of the national past help construct China's identities in different periods with different meanings. In the second place, this thesis examines not only the discourse of humiliation per se, but also the role that Japan assumes in both victim narratives and the none-victim narratives, and will utilize a social "self/other" approach to analyze Japan's role in the construction of Chinese national identity. Overall, looking back on Chinese humiliation narratives in three main periods, this thesis concludes that China's national humiliation discourse is an integral part of the shaping of national identity and Japan plays an important role in this process. It also finds out that there is no certain consistency in the interpretations of the national humiliation throughout the last 100 years in China. The national humiliation discourse had once disappeared in China during Mao's era from 1950s to 1980s. However, whether humiliation discourse dominants Chinese civil society or 
not, the ruling governments always play an essential role in shaping the nation's identity. Besides, Japan has been an indispensable "other" in China's construction of national identity. The popularization and intensification of humiliation discourse in China have always associated with anti-Japanese sentiments. Therefore, in Chinese context, Japan always assumes the role as an "enemy" when the humiliation/victim narrative dominates the civil society. 


\section{Introduction}

In December 2012, People.com released an article-2012 Report of China Internet Public Opinion Analysis. According to this report, Diaoyu/Senkaku islands dispute and the anti-Japanese demonstrations rank the first with $177,420,901$ online posts on them. ${ }^{1}$ The Diaoyu/Senkaku dispute between China and Japan has not only drawn public attention to the Internet, but also caused nation-wide anti-Japanese demonstrations in China. In September 2012, anti-Japanese protests and demonstrations broke out in at least 52 major cities of China. Tens of thousands of Chinese people had participated in this wave of anti-Japanese demonstrations and expressed their anger after Japanese government announced the decision to nationalize of the controversial islands. However, this Report of China Internet Public Opinion Analysis also reported that among demonstrators who smashed Japanese cars and beat Japanese employees in Hunan Province, some of them even did not know where the controversial islands were. Nevertheless, these people still directed their "anger spearhead" at the Japanese. In this sense, it seems to be a sort of sentiment rooted deeply in Chinese mind. If we look back on those anti-Japanese protests since the early-2000s, they may give us a clue to this sentiment.

On September $18^{\text {th }}, 2003$, a sex party held by Japanese businessmen in Southeast China attracted public attention. In fact, this event itself was not a big deal, but it happened on a sensitive day, at that day in 1931, Japanese military invaded the north part of China. Thus, it stirred another anti-Japanese protest online. According to a survey on Sohu.net, $90 \%$ of respondents considered that the Japanese tried to insult

\footnotetext{
1 “Renminwang Yuqing Jianceshi Fabu '2012nian zhongguo hulianwang yuqing fenxi baogao"” ("People.com public opinion inspection office published '2012 Report of China Internet Public Opinion Analysis'"), (2012, November 21), People.com. Retrieved October 20, 2013, from: http://yuqing.people.com.cn/n/2012/1221/c210123-19974822.html.

It is worth mentioning that among the top 10 topics, the top 6 are concerning China's international images, including China's territorial disputes with Japan and the Philippines, China's new achievement in space flight areas, the comparison of 2008 Beijing Olympics and 2012 London Olympics, the popular Chinese cuisine documentary's success around the world and the first Chinese writer who won the Nobel Prize in Literature. The common emotion behinds these topics are a mix of a sense of pride of a powerful China in terms of technology and culture and concerns about a "soft" China in terms of military.
} 
and humiliate China by their dirty action. ${ }^{2}$ Just one month later, in October, a Japanese-style skit performed by three Japanese students and their Japanese teacher in North-western University provoked an anti-Japanese demonstration of 7,000 people. ${ }^{3}$ During the demonstration, people burned Japanese flag outside the Japanese students' dormitory and shouted "Ribengou gun" (Japanese dogs, get out) ${ }^{4}$ As for the cause of this anti-Japanese protest, it was reported that a logo that read "This is the Chinese" paste on one of the Japanese student's back finally aroused Chinese students' great anger, and made them feel humiliated. ${ }^{5}$ In August 2005, an online petition was conducted against Chinese government's decision to grant a multibillion-yuan train contract with a Japanese company. Interestingly, the address of their Patriot Alliance Web was www.1931-9-18.org, one of the humiliation days that Chinese people bear in their minds. ${ }^{6}$

It's not difficult to find that the feeling of humiliation underlies all the incidents above. It is this feeling of "being humiliated" by the Japanese triggers Chinese people's antiJapanese emotions and actions in recent years. As the 2012 report of China Internet Public Opinion Analysis concludes, the emotion showed in those Chinese antiJapanese protests is a sense of humiliation rather than a sense of pride. "If we consider the prevalent patriotism in 2008 was a sense of national pride" it argues, "then the patriotism theme in 2012 reveals oppression, grievance and outrage". ${ }^{7}$ Of course, Chinese people would not feel humiliated merely due to the sex party and Japanesestyle skit; the fundamental reason is, as this article argues, the Chinese "memory of

\footnotetext{
${ }^{2}$ Kahn, Joseph. "China angered by reported orgy involving Japanese tourists," New York Times, (2003, September 30), p.A5.

3 Japanese students and their teacher wore red bras over their t-shirts, and pranced around stage throwing the stuffing at their audience. In Japan, such skits are apparently seen as humorous; in China, it was seen as lewd and offensive. See "Xibei daxue fasheng xuesheng kangyi riben liuxuesheng xialiu biaoyan shijian" ("Students of North-western University protested Japanese students' ‘dirty' performance”). (2003, October 31), Shouhu News. Retrieved on October 2, 2013, from: http://news.sohu.com/89/04/news215030489.shtml.

4 "Xi' an kangri shiwei yuyan yulie" ("The Xi' an anti-Japanese demonstrations get fiercer and fiercer"), Sing Pao Daily, (1 November 2003). Retrieved on December 2, 2013, from: http://www.singpao.com/20031101/international/470627.html.

5 Postgraduate BBS of JiLin University. Retrieved on December 2, 2013, from: http://bbs.jlu.edu.cn/cgibin/bbsanc?path=/groups/GROUP_1/Postgraduate/D8181B436/D8C6D3F95/D85DE5B31/M.1067686766.A

${ }^{6}$ Cai, Jane. "Patriots' website closed because of railway protest; anti-Japan stance over bullet-train bids too sensitive for authorities," South China Morning Post, (2004, September 1). Retrieved on October 23, 2013, from:http://www.scmp.com/article/468585/patriots-website-closed-because-railway-protest.

7 See "Renminwang Yuqing Jianceshi Fabu '2012nian zhongguo hulianwang yuqing fenxi baogao"” ("People.com public opinion inspection office published '2012 Report of China Internet Public Opinion Analysis'”).
} 
history". At present, nearly every Chinese people's anti-Japanese protest can be attributed to historical issues. According to a public survey in 2011, 74.2 percent of ordinary people and 71.2 percent of students who hold negative views on Japanese because "Japan has invaded China". 8 In this sense, controversial actions done by either Japanese government or Japanese ordinary people can easily arouse Chinese people's sense of humiliation. Therefore, it seems that there is a close connection between Japan and the humiliating narrative. There is no denying that Chinese people have suffered a lot in the Second Sino-Japanese War (1937-1945), and the mental trauma has deeply embedded into the old generation's mind. Yet, it is worth mention that direct experience of the war and the meaning attached it are not the same. Although almost all Chinese people have not experienced that war themselves, they still feel humiliated by the Japanese.

Thus, it is natural to ask where does this sense of humiliation come from? What is this sense of humiliation? Whether there has been a certain consistency in the interpretation of humiliation throughout the last one hundred years in China? And what kind of role does Japan play in Chinese narrative of "national humiliation" in different periods of time? In other words, is Japan always considered as a country that exerted "humiliation" on China in the past century? In order to answer these questions, this thesis first will look at those literatures concerning the above questions to find some clues first.

For those literatures on Chinese national humiliation, a considerable proportion of them link it to Chinese nationalism. Some of them tend to treat the sense of humiliation as an origin of Chinese nationalism. For instance, Zhang Tiejun believes that there are two important historical factors which help constructed today's Chinese self-identity: "central kingdom" complex and "strong China" complex. The former one is generated from the ancient time, when China was the center of East Asian civilization. While the latter implies that the humiliation experience in early modern

8 "2011 Zhongri guanxi yulun diaocha baogao" ("Report of public opinions on Sino-Japanese relations, 2011"). China Daily. Retrieved on October 17, 2013, from: http://www.chinadaily.com.cn/hqjs/201108/04/content_13092005.htm. 
China has become a strong motivation for both Chinese elites and ordinary people to surpass the West and Japan. ${ }^{9}$ Yuan Jingdong concurs with Zhang on this point; he argues that Chinese nationalism falls into two categories. One is the pride in its glorious civilization, and the other one is kind of sentimental nationalism as a consequence of the hundred year's invasion of the Western countries and Japan. ${ }^{10}$ Gregory Moore considers that the "Century of Humiliation" (1840s -1940s) is one of the sources of China's resurgence of nationalism. ${ }^{11}$ Other scholars highlight the role of the Chinese Communist Party (CCP) in nationalistic propaganda, which is characterized by the narrative of national humiliation. ${ }^{12}$ The similar argument of these studies is that after 1989 Tiananmen Incident, Chinese leaders quickly began to emphasize its status as the highest and strongest nationalist power and a defender of national pride. For instance, Christopher Hughes argues that the concepts like "national unification" and "against hegemony" were instilled as a new ideology in the 1980 s, and he further points out that this nationalistic infusion of ideology has resulted in a furious nationalism sentiment ten years later. ${ }^{13}$ In this context, "the more the party is seen to be taking a hard stance against any perceived 'revival' of 'Japanese militarism', the more likely it is to be seen as a patriotic force worthy of the people's backing."14 Although these literatures provide us certain point of views to see the relation between Chinese sense of humiliation and its nationalism sentiment in recent two decades, they do not pay much attention to the concept "humiliation" itself and how this concept was interpreted by either Chinese governments or the public before the 1980 s.

As for how can we understand "national humiliation", David Campbell gives us a

\footnotetext{
9 Zhang, Tiejun. (2004). "Self-Identity Construction of the Present China," Comparative Strategy, 23(3):281-301.

${ }^{10}$ Yuan, Jingdong. (2008). "Chinese Nationalism and Sino-Japan Relations," Pacific Focus, 23(2): 212-231.

11 Moore, Gregory J. (2010). History, Nationalism and Face in Sino-Japanese Relations, Journal of Chinese Political Science, 15, 283-306.

12 Whiting, Allen S. (1995). "Chinese Nationalism and Foreign Policy after Deng," The China Quarterly 142, p.316; Zhao, Suisheng. (2005). “China's Pragmatic Nationalism: Is it Manageable?” The Washington Quarterly 29(1): 131-144; Hughes, Christopher R. (2006), Chinese Nationalism in the Global Era, NewYork: Routledge; Gries, Peter H. (2005). "A Preliminary Analysis of Chinese Nationalism: The People, Their Pasts, and Their Passions," World Economics and Politics, 11: 42-48; Kang, Su-Jeong. (2013). "Anti-Japanese Popular Nationalism and China's Approach Towards Japan amid Sino-Japanese Political Tension, 2001-2006,” East Asia, 30: 161-181.

${ }_{13}$ Hughes, Christopher R. (2006). Chinese Nationalism in the Global Era, NewYork: Routledge.

14 Suzuki, Shogo. (2007). "The Importance of 'Othering' in China's National identity: Sino-Japanese Relations as a Stage of Identity Conflicts," The Pacific Review 20(1), p.26.
} 
good angle to understand "national humiliation". He says, "National humiliation is considered an example of either (1) a determinist notion of primordial national history that naturally defines eternal enemies, or (2) a political culture that is manipulated by elites in power politics." 15 In Chinese scenario, the second explanation of "national humiliation" has won the favor among scholars. As we mentioned above, the majority of analysts prefer to stress CCP's crucial role in mobilizing the mass public by using nationalism rationally. William Callahan's two articles offer an overall look at the nation-led narrative of China's national humiliation. In National Insecurities: Humiliation, Salvation and Chinese Nationalism, Callahan points out that the discourse of national humiliation has been "a common and recurring theme in Chinese public culture."16 In this sense, unlike the above articles that focus on the role of the Communist Party alone, Callahan believes that the role of the Chinese society and the Nationalist Kuomin Party (KMT) cannot be ignored in the spread of "national humiliation" discourse. In History, identity, and security: Producing and consuming nationalism in China, Callahan uses "National Humiliation Day" as an indirect entry to examine China's national identity. According to the change of the "National Humiliation Day" from 1915 to the new century, this article contends "new enemies generate new humiliations, which in turn not only lead to a quest for military strength to deal with foreign threats, but to a new construction of national identity to rally the masses at home." 17 Overall, these two articles provide us a good angle to examine China's nationalism from a "national humiliation" perspective. However, Callahan only puts the narrative of "national humiliation" into the pre-1949 and post-1980s context without mentioning the interpretation between the $1950 \mathrm{~s}$ to the $1980 \mathrm{~s}$. Similarly, although it points out "new enemies generate new humiliations", there is an absence of explanation about the situation in Maoist age, in which even though the KMT regime and its US ally had substituted Japan as China's top "enemy".

\footnotetext{
15 Campbell, David (1998). National Deconstruction: Violence, Identity, and Justice in Bosnia, Minneapolis: University of Minnesota Press, p. 67. Quote from: Callahan, William (2004). "National Insecurities: Humiliation, Salvation and Chinese Nationalism," Alternatives: Global, Local, Political, 29(2), p.203.

16 Callahan, William A. (2004). "National Insecurities: Humiliation, Salvation and Chinese Nationalism," Alternatives: Global, Local, Political, 29(2), p.214.

17 Callahan, William A. (2006). "History, identity, and security: Producing and consuming nationalism in China," Critical Asian Studies, 38(2), p.192.
} 
In this regard, He Yinian's article can be seen as a good complement of the above two. In his Remembering and Forgetting the War: Elite Mythmaking, Mass Reaction, and Sino-Japanese Relations, 1950-2006, He stresses the indispensable role of Chinese ruling political elites on China's "history construction". By answering the question "Why did not China and Japan started the quarrel about history until more than three decades later, the early 1980, when the majority of the population no longer had direct experience of the war and the two countries had developed close economic and social ties?"18 He finds out that the fundamental cause of Sino-Japanese political disputes and conflicts is the "history issues" which manipulated by the communist ruling elites for instrumental purposes. More specifically, He argues that the political elites of China only resort to the "history issue" at international level when they feel threats from domestic opposition forces. Although He raises a good question, he does not give a comprehensive answer to it. To be more specific, if we look at this question from a broader view, and take the pre-1949 regimes after Qing Dynasty into account, the "history issue" is not only used by the CCP government but also utilized by the KMT government to mobilize the mass during wartime.

As for the first explanation of "national humiliation" by Campbell, though it is less popular than the second one, some analysts do provide us with a good lens to see the role of the perceived "enemies". Suzuki Shogo tries to examine Japan's role in the construction of China's national identity from a social "self/other" perspective. She contends that a sense of "victimhood" could be seen as the main character of China's national identity, and Japan has always assumed the role as an "other" or an "enemy" in the construction of Chinese national identity. In this sense, Japan's role will enhance China's self identity as a "victim". In contrast to those who exaggerated CCP's role in infusing the public with the victim narrative, Suzuki attaches more significant on the influence of the history itself. As she argues, "history is more than just part of a 'tool kit' that can be rationally utilized by the political elite, and that

\footnotetext{
${ }^{18}$ He, Yinan. (2007). "Remembering and Forgetting the War: Elite Mythmaking, Mass Reaction, and SinoJapanese Relations, 1950-2006," History and Memory, 19(02), p.44.
} 
states are moral agents that are deeply affected by history." 19 Therefore, from her perspective, Japan's role as an immoral "other" is not invented by the authorities. On the contrary, it has deeply rooted in Chinese people's mind, including those ruling elites. Although Suzuki's article highlights the nature of Japan's negative history in the process of China's identity construction, it fails to explain the question why there is a once a silence in the history disputes between these two countries. In this respect, even though real history plays a significant role in Sino-Japanese relations, the official interpretation of the existing history cannot be ignored to understand relations between China and Japan.

Based on the above literatures, this thesis tries to give a more comprehensive picture of the origin and evolution of the narrative of national humiliation and the role Japan plays in this narrative. First, different from the existing literatures, this thesis mainly focuses on narratives of humiliation/victim in different periods of China since its popularization in 1915. To be more specific, it intends to examine this victim narrative in the following three main periods chronologically: the origins and evolution of "national humiliation" in the pre-1949 era, the lack of "national humiliation" from the 1950 s to the 1980 s, and the reinvention of "national humiliation" in the post-1989 era. Second, by using substantial documents, this thesis will analyze humiliation discourses in each period from various aspects, including, public speeches of leaders, school textbooks, state-run newspapers, publications, films, etc. to find out whether the national humiliation discourse dominates Chinese civil society, and if not, what the alternative narrative it is. Overall, through using "national humiliation" discourse as an entry to analyze China's national identity, it tries to argue that China's humiliation discourse is an integral part of the shaping of national identity. Third, this thesis intends to analyze not only the discourse of humiliation per se, but also the role that Japan assumes in both victim narratives and the none-victim narratives. As mentioned above, there is a connection between Japan and Chinese national humiliation narrative. As Callahan says, different "enemies" will generate

\footnotetext{
19 Suzuki, Shogo. (2007). "The Importance of 'Othering' in China's National identity: Sino-Japanese Relations as a Stage of Identity Conflicts," The Pacific Review, 20(1), p.23.
} 
different humiliations, which in turn require different construction of national identity. In this regard, like Suzuki, this thesis tries to utilize a social "self/other" approach to analyze Japan's role in the construction of Chinese national identity.

With respect to the structure for this thesis, in the first section (The Century of Natioanl Humiliation), it will give a clear explanation of why the narrative of national humiliation emerges in Chinese civil society, and examine the content of the national humiliation discourse. In the second section (Victim Narrative in the Pre-1949 Era), it will focus on the origins and evolution of the humiliation discourse in the pre-1949 Republic of China (ROC) period. More specifically, the pre-1949 Republic period can be divided into two parts: Beiyang government (1912-1927) and the Nationalist KMT government (1927-1945). As for Japanese role in this period, though the "Century of National Humiliation" discourse involves both the Western countries and Japan, the Japanese had gradually become the primary "enemy" of Chinese due to Japanese military's continuing aggression. In the third section (The Absence of Victim Narrative in China's Civil Society, 1950s-1980s), it will look at the period from the 1950s to the 1980s, in which national Mao's class-based ideology and Deng's pragmatic philosophy dominated the society separately. This thesis intends to divide this period into two subparts: Maoist era (1949- the late 1970s) and a pragmatic China under Deng (1970s-1980s). Moreover, it tries to examine whether the victim narrative was still the main theme in these two periods, and if the answer is no, what were the alternative narratives. In the fourth section (The Revival of Victim Discourse since the Late-1980s), it will focus on the post-1989 era, when the "Patriotic Education Campaign" was launched by the government. During this "Patriotic Education Campaign", the narrative of "national humiliation" has been increasingly embedding within government organizations, popular culture, and public media. 


\section{The "Century of National Humiliation"}

Chinese sense of national humiliation derives from the huge psychological gap between its central status of the Eastern Asian during its 5,000-year civilization and the invasion by foreign imperialists since the $19^{\text {th }}$ century. The pride from China's 5,000-year civilization and the stigma in China's 100-year humiliation by the West and Japan together construct the narrative of its past. Base on the glorious 5,000-year civilization in the past, history of being invaded by the foreigners makes the Chinese feel difficult to accept, and the gap between the past prosperity and what happened in contemporary China let Chinese to define the later as a "humiliation". As Gries comments, "the 'Century' threatened a Chinese identity based upon the idea of a universal and superior civilization - the '5,000 years.' ${ }^{20}$ Chinese pride of their 5,000-year civilization is one of the essential points to understand the current humiliation discourse in China. It is easy to find Chinese "pride of history" from daily news or articles. For instance, Beijing Youth Weekly once published an article named “Chinese beat Garry Kasparov!" in 1997. The article claimed that it was two America born Chinese programmers that beat Mr. Kasparov. It finally concluded that all the achievements in China today are derived from the 5,000-year civilization heritage, and we Chinese should be proud of it. ${ }^{21}$ This logic of thinking is quite pervasive in contemporary China. It is not exaggerating to say that the "5,000-year civilization" has become as a burden for China. The glorious civilization in ancient China make Chinese people feel difficult to accept the truth that it has been aggressed by the Western countries, let alone Japan-once was a vassal country in Chinese Empire from 1842 to 1945 . Thus, the narrative of the "Century of National Humiliation" emerge to show a sense of loss, which came from the gap between a "world empire" and "a chunk of meat on the chopping block".

The narrative of the "Century of National Humiliation" determines the way how

\footnotetext{
20 Gries, Peter H. (2005).”Nationalism, Indignation and China's Japan Policy,” SAIS Review, 25(02), p.109.

21 "Women you Zuiyouxiu de Rennao" ("We have the most brilliant brain"), (1997), Beijing Youth Weekly, 98: 30.
} 
Chinese deal with the Western and its immediate neighbor-Japan. As many textbooks tell, this century began with the Opium Wars (1840-1842), in which the Qing Dynasty was defeated by the army of British and was forced to accept an unequal treaty_ “"the Treaty of Nanjing”. According to the treaty, Qing court not only had to open its markets to British opium, but also needed to cede five coast cities (Guangzhou, Fuzhou, Xiamen, Ningbo and Shanghai) to British as free ports and gave Hong Kong to the British government. China's defeat in the Opium War symbolized the collapse of the old empire and the start of national humiliation. Later on, the Second Opium War (1856-1860) was launched by the joint army of British and French. The results of this war were: first, Qing Dynasty had to open more ports cities for trade; second, it lost 1,500,000 $\mathrm{km}^{2}$ northern territorial areas to Russia who participated in the war just as a mediator. Apart from the economic and territory loss, another symbolic event happened during this war was the occupation and loot of the Yuan Ming Yuan Garden. The ruins of this former royal garden seem to leave a profound psychological trauma on Chinese from generation to generation. According to $\mathrm{Wu}$, the ruin of Yuan Ming Yuan is "the first and most important modern ruin in China", ${ }^{22}$ and now it still serves as remains of Chinese humiliating history.

If the wars in China is considered as inevitable experiences of an Asia country who confronted with the West-led international society at the first time, or as a throe of transformation from an empire to a barbarian in the Westphalian system as some English school scholars believe, ${ }^{23}$ Japan is always an exception. Japan faced a similar situation with China in the middle of $19^{\text {th }}$ century, but it had stepped on a different route. After forced to open its door by the American, Japan decided to learn from the Western and then launched the Meiji Restoration in 1868 which brought Japan into a status as one of the powers in the world.

As a consequence, in 1895 Japan defeated China in the first Sino-Japanese War and

\footnotetext{
22 Wu, Hung. (1998). "Ruins, Fragmentation, and the Chinese Modern/Post- modern," in Gao, Minglu, ed., Inside Out: New Chinese Art, San Francisco: San Francisco Museum of Modern Art, p. 60.

${ }^{23}$ Gong, Gerrit W. (1984). The Standard of Civilization in International Society, Oxford: Clarendon Press, pp.5165; Zhang, Yongjin. (2001). "System, empire and state in Chinese international relations," Review of International Studies, 27(05): 43-63.
} 
imposed another unequal treaty on Qing court. "Treaty of Shimonoseki” required Qing to cede the Penghu group, Taiwan and the eastern part of Liaodong Peninsula in perpetuity. And this treaty confirmed the opening of seven ports (Beijing, Shashi, Chongqing, Suzhou, Hangzhou, Xiangtan, Wuzhou) to Japanese trade. So far, Japan had transformed from a vassal country in Empire system to a powerful sovereign state in Westphalian system while China was still struggling with the everchanging environment. The 1895 Sino-Japanese War reveals the antagonistic history between China and Japan. More importantly, it brought an extensive debate among Chinese elites on nationalism, and inspired the Chinese to set up their mind to rebuild China as an independent and strong state in the international community. Although the "Century of National Humiliation" started in the middle of $19^{\text {th }}$ century, national humiliations day in China was not emerged until 1915, when Japanese imperialist imposed the unequal treaty "Twenty-one Demand" on Chinese government.

As its military capability grew, Japanese finally engineered the invasion to the northern part of China. On September 18 ${ }^{\text {th }}$, 1931, Japan occupied Manchurian and supported the last Qing court's Xuantong Emperor Puyi as the emperor of Manchukuo. The occupation of northern China was the first step of Japanese strategy in China. On July $7^{\text {th }}, 1937$, Japanese army's invasion of eastern China finally triggered the second Sino-Japanese War (1937-1945), which was an integral part of Japanese military's strategy of building the "East Asian Co-Prosperity Sphere". Therefore, to conquer the whole country became an imperative step to realize Japanese "goal", but at the same time, the Chinese has suffered considerably in wartime. During the second SinoJapanese War, Japan had once occupied vast Chinese territory and its army did committed war crime against Chinese civilian. Among those crimes, Nanjing Massacre and the activities of Japan's Unit 731 are considered as typical examples of the crimes of Japanese military by the Chinese. In the case of Nanjing Massacre, over 300,000 civilians were killed by the Japanese army according to Chinese official data. ${ }^{24}$

\footnotetext{
${ }^{24}$ Some scholars consider that Chinese leaders set the numbers of victims in Nanjing Massacre at a high level intentionally. See Coble, Parks M. (2007). "China's "New Remembering" of the Anti-Japanese War of Resistance, 1937-1945," The China Quarterly, 190: 394-410.
} 
Moreover, it is reported that 20,000 to 80,000 Chinese women were raped by Japanese soldiers during their invasion and occupation of Nanjing. ${ }^{25}$ As for the activities of Unit 731 in Northeast China, Harbin, Japanese scientists used Chinese prisoners to conduct experiments "from the study of the Bubonic Plague to vivisections". It is estimated that ranging from 3,000 to 10,000 Chinese lost their lives at the camp of Japanese Unit $731 .{ }^{26}$

Based on the above history, the "Century of National Humiliation" is not merely an invention of Chinese elites to motivate the mass population, it is a century, in which Chinese people did suffer tremendously, and the memories of the wartime have deeply rooted in Chinese people's mind. However, apart from the history itself, the narrative of history is also significant in constructing a nation's identity. In the next few sections, the author will focus on the government's interpretation of Chinese history in both pre-1949 period and post-1949 periods to find whether there has been a certain consistency in the interpretation of the humiliation discourse in the past 100 years since the concept was invited to the public.

\section{Victim Narrative in the Pre-1949 Era}

To some scholars, only Chinese Communist Party $(\mathrm{CCP})$ relies on the victim narrative which used as a tool to mobilize the public. Moore argues that the Communist state has been working hard to "create a sense of nationhood among all its citizens" by the help of nationalism. ${ }^{27}$ It is true that the communist party plays an important role in national propaganda. However, in the pre-1949 era, governors, intellectuals, merchants as well as students cannot be ignored in the process of creating and popularizing the narrative of national humiliation. In other words, the propaganda of

25 Chang, Iris. (1997). The rape of Nanking: the forgotten holocaust of World War II. New York: Basic Books. P.6. ${ }_{26}$ Moore, Gregory J. (2010). "History, Nationalism and Face in Sino-Japanese Relations," Journal of Chinese Political Science, 15, p.289.

27 Zhao, Suisheng. (1998). "A State-Led Nationalism: The Patriotic Education Campaign in Post-Tiananmen China," Communist and Post-Communist Studies, 31(3): 287-302. 
national humiliation is not exclusively used by CCP. According to Callahan, "patriotism and national humiliation were also closely linked in editorial commentaries and history textbooks in early twentieth century." 28 Thus, it is neither a new policy in the period of the KMT's Republic of China (1927-1948), nor "a twentyfirst-century phenomenon", ${ }^{29}$ it has been an essential part of the common historical narrative since the early 1900s. Therefore, the discourse of national humiliation is a recurring theme existed in both pre-1949 regimes and post-1949 communist China. It is also worth mentioning that though this "Century of National Humiliation" discourse involves western countries and Japan, Japan was Chinese people's primary “enemy", which can be observed through the establishment of "National Humiliation Days" and the increasingly-enlarged influence of the national humiliation discourse during the pre-1949 era.

\section{The origin of humiliation narrative during Beiyang government (1912-} 1927)

The humiliation discourse first emerged in January of 1915 when Japan imposed an unequal treaty_-“Twenty-one Demand” on Chinese Beiyang government (1912-1927), which seriously violated Chinese national sovereignty. Although, "there was talk of China being humiliated before 1915, the discourse of national humiliation in an organized form dates from 1915"30. After the final signing of this "Twenty-one Demand" with Japan on May 9 ${ }^{\text {th }}, 1915$ made by Beiyang government, the public tended to mark this event as a national humiliation. The slogan "Never forgot National Humiliation" was "painted on walls, coined into trade-marks, and imprinted on stationery"31 and this sentence was soon added into the content of school textbooks to

${ }^{28}$ Callahan, William A. (2006). "History, identity, and security: Producing and consuming nationalism in China," Critical Asian Studies, 38(2), p.185.

29 Callahan, William A. (2004). "National Insecurities: Humiliation, Salvation and Chinese Nationalism,"

Alternatives: Global, Local, Political, 29(2), p.210.

30 Ibid.

31 Luo, Zhitian. (1993). "National Humiliation and National Assertion: the Chinese Response to the Twenty-one 
let the youth never forget this humiliation. This sentiment had been embedding into citizen's everyday lives during that period. On May 20 $0^{\text {th }}$, Jiangsu (province) Educational Association accepted a Chinese business man's proposal to mark the May $7^{\text {th }}$, when the Japanese gave Chinese government the ultimatum, as the "National Humiliation Day". ${ }^{32}$ Although national humiliation day was not a legal holiday at that time, Beiyang government gave their tolerance to social groups and people in schools to commemorate it themselves. Therefore, each year on this day, a large number of anti-Japanese movements were organized by those social groups throughout China, which includes: rallies, boycotts of Japanese products, and activities organized by the overseas Chinese and students. Later, this "National Humiliation Day" was continued by the KMT regime officially from 1927 to $1940 .{ }^{33}$

During the period of Beiyang government, representatives of social power, for example, students, intellectuals, merchant groups, rather than the government showed more anger to this unequal treaty, and displayed more passion to popularize the discourse of "national humiliation" in order to mobilize all Chinese people to against Japan. Young people always wore armbands marked "national humiliation", draw pictures onto street walls and made public speeches in front of street theatre to show how vicious the Japanese was. ${ }^{34}$ Chinese intellectuals initiated a lot of public publications, in which showed a strong sense of humiliation. Soon after the signature on the "Twenty-one Demands", a book named Wuyuejiuhao Guochishi (History of May $9^{\text {th }}$ National Humiliation Day $)^{35}$ was published. Aiming at arousing Chinese national spirit and keeping this national humiliation in mind everlastingly, this book collected numerous negotiation documents between Beiyang government and Japan as well as editorials on this unequal treaty from influential newspapers in China. Later, a magazine named Guochi (National Humiliation) and a book similarly entitled Guochi

Demands," Modern Asian Studies, 27(2), p.310.

32 Ibid. May $7^{\text {th }}$ is the day when the Japanese gave Beiyang government the ultimatum.

33 The Nationalist KMT government changed the National Humiliation Day from May $7^{\text {th }}$ to May $9^{\text {th }}$, in which the Yuan government singed the "Twenty-one Treaty" with Japan.

34 "Yongyuan buwang: guochi jinian xiaoshuo" ("Never forget: A national humiliation commemorative story"), Shenbao, (1928, May 9).

35 Yi, Yin. (1915). “Wujiu guochishi” ("History of May 9 Humiliation”). Shanghai: Guowen Shuju. 
were also published in the year $1915 .{ }^{36}$ Since then, Chinese patriotic intellectuals had started to construct "national humiliation" as a collective memory intentionally. As for Chinese merchants, some of them chose to hang national humiliation flags and banners outside and reserved their stores for one day to commemorate the national humiliation. The contents of those banners were often "May $9^{\text {th }}$, do not forget the national humiliation", "Return our territories-Dalian and Lvshun", ${ }^{37}$ "Annulling the Twenty-one Demand", etc. Others decided to continue their businesses but donated sales turnover on national humiliation day to a foundation sponsored by various commercial chambers in order to redeem the reparations. ${ }^{38}$ In addition, commodities embalming "national humiliation" also stood out at that time to meet the popular need-“Cleansing National Humiliation". For instance, a towel company had designed its advertisement to lead its consumers to link washing face to washing away national humiliations. ${ }^{39}$ For ordinary Chinese, the best way to express their indignation towards "Twenty-one demands" was the movement against Japanese goods. Since then, boycotting Japanese goods had been served an indispensable "tool" among Chinese when dealing with Japan until "New China" was built in 1949 by the communists. Interestingly, half of a century later, since the early-2000s, this traditional action has recaptured by Chinese nationalists when China has diplomatic disputes with Japan.

The popularization and intensification of national humiliation discourse among Chinese was associated with the upsurge of Chinese people's anti-Japanese sentiment. If we consider the event happened in 1915 as the beginning of both the discourse of national humiliation and anti-Japanese sentiment, then the May Fourth Movement (1919) could be seen as the climax of both of them, and in turn, deepened the feeling of national humiliation as well as the anti-Japanese sentiment. Initiated by college

\footnotetext{
${ }^{36}$ Cohen, Paul A. (2002). "Remembering and Forgetting: National Humiliation in Twentieth-Century China," Twentieth-Century China, 27(2): 4-17.

37 They are two Chinese northeast coastal cities that Yuan shikai government ceded to Japan in "Twenty-one Demand".

38 "Shandonglu shanglianhui zhiwujiuchi" ("May 9 humiliation of Shangdong Road commercial chamber"), Shenbao, (1922, May 8), p.13.

39 Shenbao, (1925, May 9). Quote from: Callahan, William A. (2006). "History, identity, and security: Producing and consuming nationalism in China," Critical Asian Studies, 38(2), p.202.
} 
students, the target of the movement aimed at protesting Chinese government's response to the "Treaty of Versailles" which grants territories in Shandong to Japan after the surrender of Germany. On May $4^{\text {th }}$, more than 3,000 college students in Beijing marched in front of Tiananmen, and chanted "Abolish the 'Twenty-One Demands", "Struggle for the sovereignty" and "Beat the imperialistic Japanese". In addition, students in Beijing called for a large scale of boycott of Japanese products. Tsinghua University's students even burned Japanese goods on campus to vent their anger. The May Fourth Movement can be considered as a prelude to the mass demonstrations of Chinese students. Since then, anti-foreign imperialism, especially anti-Japanese, has become an integral theme among Chinese nationalists. The slogan like "Beat the imperialistic Japan" and the actions like boycotting and burning the Japanese goods in the May Fourth Movement are still used by Chinese nationalists today in anti-Japanese protests.

\section{"National humiliation" in Kuomin Party (KMT) government and Japan as a "national enemy"(1927-1948)}

Since 1927, when Kuomin Party (KMT) troops nearly controlled the whole country, the discourse of national humiliation had gradually served as a government instrumental tool to "construct citizenship and national identity in the Republic of China" 40 . The commemoration of "National Humiliation Day" was carried on when KMT took over the power, and finally it was acknowledged legally in $1928 .{ }^{41}$ Since then, the KMT authority had used its political power to narrate "national humiliation" nationwide. Differing from Beiyang government period, in which social groups rather than the government played a more essential role in popularizing the narrative of "national humiliation", "national humiliation" had served as a tool of the KMT

\footnotetext{
${ }^{40}$ Callahan,William A. (2006). "History, identity, and security: Producing and consuming nationalism in China," Critical Asian Studies, 38(2), p.185.

41 The Nationalists Party changed the National Humiliation Day from May $7^{\text {th }}$ to May $9^{\text {th }}$, in which the Yuan government singed the "Twenty-one Treaty" with Japan.
} 
government to unify the entire country since it took the power in 1927.

In the first place, KMT government inherited the national humiliation narrative from the previous government, and then summarized all the national humiliation days, which had been commemorated by the public privately, into a national calendar. Since China had been "humiliated" by foreign imperialists numerous times started from the Opium War, the KMT government issued an official calendar that contained totally 26 national humiliation days, which were commemorated by the public privately, throughout the year. ${ }^{42}$ Through "nationalizing local customs" and inheriting the commemoration of national humiliation days, KMT government showed its intention of utilizing the "national humiliation" myth to construct a uniform national identity, that is "a 'China' worthy of being saved". ${ }^{43}$

In the second place, KMT government gradually reset the "National Humiliation Days" throughout the whole nation. In May 1928, when KMT's Northern Expedition was going to complete, Cai Yuanpei, the director of Education Ministry of KMT government, sent a telegram to colleges and provincial education departments nationwide. According to this telegram, all schools should commemorate the "National Humiliation Day" from $7^{\text {th }}$ May to $9^{\text {th }}$ May. ${ }^{44}$ It was the first time that the importance of "National Humiliation Day" was stressed in the education fields put forward by the government. One year later, on $1^{\text {st }}$ July, 1929, KMT government passed the list of revolution memorial days in the party's $20^{\text {th }}$ central standing committee conference, in which "National Humiliation Memorial Days" were set as the following: $3^{\text {rd }}$ May, Jinan Incident national humiliation day,45 $9^{\text {th }}$ May, "Twenty-one Demand" national humiliation day, $30^{\text {th }}$ May, Shanghai Incident national humiliation day; ${ }^{46}$

\footnotetext{
42 Lian, Xinbian. (1966). "Guochi shiyao" ("Brief history of National Humiliation”). She, Yunlong (Ed.) Jindai Zhongguo Shiliao Congji, vol.90. Taipei: Wenhai Chubansh.

${ }^{43}$ Callahan, William A. (2006). "History, identity, and security: Producing and consuming nationalism in China," Critical Asian Studies, 38(2), pp.179-208.

44 "Guochi jijian" ("Memorial of national humiliation"), Zhongyang Ribao (Central Daily News) (1928, May 7), p.3.

45 On May $3^{\text {rd }}, 1928$ (during KMT's Northern Expedition), Japanese military killed thousands of Chinese civilians and soldier on an excuse of protecting Japanese citizens in Jinan.

46 On May $30^{\text {th }}$, 1925, a Chinese worker was killed by his Japanese employer in factory.
} 


\section{$23^{\text {rd }}$ Jun, Shaji Incident national humiliation day; ${ }^{47} 29^{\text {th }}$ August, Treaty of NanJing} national humiliation day, ${ }^{48} 7^{\text {th }}$ September: the Boxer Protocol national humiliation day. ${ }^{49}$ The conference decreed that the whole nation was required to hang flags at half-mast in the first four national humiliation days, but "National Humiliation Days" could only be commemorated by those selected delegates of official institutions, people in schools, and social groups in formal rituals. ${ }^{50}$ Moreover, KMT government proclaimed that parades without official authorization would not be tolerated. In this sense, the authority had become the only legal actor to organize the commemoration of "national humiliation".

On $10^{\text {th }}$ July, 1930 , the list of national humiliation days was confirmed by the $100^{\text {th }}$ standing conference of the $3^{\text {rd }}$ KMT central executive committee again, while the number of the national humiliation days was reduced on the grounds of redundancy. From then on, $9^{\text {th }}$ May, had been the only legal national humiliation day to represent all national humiliations that Chinese people had suffered until 1940. Since 1937, the commemoration on $9^{\text {th }}$ May was combined with July $7^{\text {th }}$, in which day the Japanese forces invaded Beijing, the capital city of China. Three years later in 1940, as it proclaimed officially, "Since July $7^{\text {th }}, 1937$, the whole nation has been involved in the war of anti-Japanese. Therefore, July $7^{\text {th }}$ now serves as the 'War of Resistance commemoration day', May $9^{\text {th }}$ is no longer necessary." 51 To some degree, whether the government changed the legal "National Humiliation Day" or not, Japan was always

\footnotetext{
47 On June $23^{\text {rd }}$, 1925, based on Shanghai Incident, Shanghai citizens organized a demonstration to protest Japanese employer's inhumane behavior, but were shot by the Britain and French cops, hundreds were dead. 48 China was defeated by the army of British in the Opium War. On August 29 $9^{\text {th }}, 1842$, Qing court was forced to accept the unequal treaty- "the Treaty of Nanjing". According to the treaty, China not only had to open its markets to British opium, but also needed to cede five coastal cities and Hong Kong to British government.

49 In 1898, the Boxer Rebellion, which is motivated by nationalism and anti-imperialism, took place in China. On June $21^{\text {st }}$, 1900, Qing court authorized a war against the foreign imperialists with the Boxers. Foreigners and Chinese Christians were under siege by the Qing's force and the Boxers for 55 days in Beijing Legations. Later, the eight-nation alliance defeated the Qing's force and the Boxers and captured Beijing. As a consequence, the Qing court had to sign the Boxer Protocol on $7^{\text {th }}$ September. According to this protocol, sixty-seven million pounds should be paid as an indemnity to the eight nations involved.

${ }^{50}$ Zhang, Yan \& Sun, Yanjing. (Ed.). (2009). Minguo shiliao congkan, Zhengzhou: Daxiang Chubanshe, p.147. 51 "Zhongyang feichu wujiu jinian" ("Central government cancels May 9th commemoration"), Shenbao (1940, May 7), p.4. It is worth mentioning that there is no official "National Humiliation Day" in P. R. China at present. Nevertheless three specific dates are considered to be the "National Humiliation Day" by the general public: May $9^{\text {th }}$, September $18^{\text {th }}$, and July $7^{\text {th }}$. The similarity shared by these three dates is the involvement of Japan. On May $9^{\text {th }}$, 1915, Chinese government received the unequal treaty forced by Japan, on September $18^{\text {th }}$, 1931, Japanese force occupied the Manchurian (northeastern China), and on July $7^{\text {th }}, 1937$, Japanese army invaded China's capital city Beijing and triggered the Second Sino-Japanese War.
} 
served as a representative of those "enemies" who had humiliated Chinese for before, because May $9^{\text {th }}$ is the day that the Beiyang government received Japanese unequal treaty_-"Twenty-one Demand", and July $7^{\text {th }}$ is the day the Japanese forces invaded Beijing and triggered the Second Sino-Japanese War.

Accompanied with the reset of "National Humiliation Days" under KMT government, the role of Japanese imperialist as a "national enemy" had gradually embedded into Chinese people's mind through the propaganda of the authority. When Education Ministry of KMT government required that all schools should establish and commemorate "National Humiliation Days" from $7^{\text {th }}$ May to $9^{\text {th }}$ May, special courses must be imparted to students during these three days to let them know more about the imperialist Japan, who had humiliated the whole nation. The special courses include: 1. Nationalism; 2. Researches of Japan, for example, geography, history, population, economy, military, culture, etc.; 3. The history of Sino-Japanese relations. The objective of the generation in special courses was to let Chinese youth touch the essence of the memory of national humiliation. ${ }^{52}$ What is more, When the KMT government authorized that there were, in all, six "National Humiliation Day" deserved memorized throughout the whole year, attentions ought to be caused that Japan occupied four sixth of it. In other words, Japan was playing a significant role in the discourse of Chinese national humiliation under the control KMT government.

The narrative of "national humiliation" and Japanese role as "national enemy" were also emphasized by the practice of "National Humiliation Days". In accordance to the governmental legislation, during 1930s, the "9th May National Humiliation Day" was commemorated mainly through the "public memorial" rituals organized by local KMT offices. Local party office generally convened social representatives of all working fields to participate in the "public memorial" ritual, in the morning of $9^{\text {th }}$ May. The procedure of the ritual was uniform. Firstly, all participants stood up and sung "song of KMT party”. Secondly, participants saluted the party flag and the chairmen of the

52 "Zuori wujiu guochi jinian dahui" ("Yesterday's May $9^{\text {th }}$ memorial conference"), (1927, May 10), Shenbao, p.13. 
ritual read the will of KMT former president Sun Yat-sen. Then, everyone stands in silent tribute for three minutes. Next, the chairmen would give the main report and representatives giving speeches respectively. Finally, shout slogans together. The contents of the slogans practically were: "do not forget our national humiliation", "to revoke the consular jurisdiction", "to recover the national territorial concession", "to abolish the unequal treaties", and "to defeat the Japanese imperialist". The posters putting on the wall of the auditorium always read: "Our biggest enemy is the Japanese imperialists", "the aim of national humiliation memorials was to encourage us to put great efforts on the work of anti-Japanese", "the first step of cleansing the national humiliation was the consciousness of humiliation", "the effort on the domestic products campaign is to promote the quality of domestic goods, patriotic citizens should not buy Japanese goods", and "the atrocious Japanese is our only enemy", etc. ${ }^{53}$

Japan's increasingly deepening role in Chinese humiliation myth was reflected not only by the selection and practice of "National Humiliation Days", but also through the official propaganda goals on these days. Associated with the list of national humiliation days, a supporting document—brief history and primary propaganda task the revolution memorial days also announced to stipulate and emphasize the main propaganda tasks on those national humiliation days in 1929. Take Jinan Incident national humiliation day on $3^{\text {rd }}$ May as an example, propaganda tasks for this commemoration were: first, to denounce Japanese savage actions in city Jinan; second, to reveal Japanese imperialist's plot of sending troops to stop KMT's Northern Expedition; third, to analyze the demands of the cabinet of Japanese warlords after the Jinan Incident; fourth, to make the public known the wild scheme of Japanese imperialist; fifth, to explicate the definition of "nationalism". ${ }^{54}$ According to this list

\footnotetext{
53 See "Zhongshuju xingwujiuguochi jinian" ("Central bureau held may 9 national humiliation day memorial”), Shenbao (1929, May 10). P.6; "Shoudu gejie zuori juxing guoch ijiniandahui" ("Figures from all circles held national humiliation memorials in capital city yesterday), Zhongyang Ribao (1932, May 10), p.3; "Jinri wujiu guochi jinian" ("Recent May 9 national humiliation memorials”), Shenbao (1933, May 9) p.8; "Gejie daibiao zuori juxing wujiu guochi jinian dahui" ("Delegates from all circles held May 9 national humiliation memorials yesterday"), Shenbao (1934, May 10). p.10.

${ }_{54}$ Zhang, Yan \& Sun, Yanjing. (Ed.), (2009). Minguo shiliao congkan, Zhengzhou: Daxiang Chubanshe, p.147.
} 
of propaganda tasks, there is no doubt that Japan had been constructed as one of the major "others" or even a "national enemy" by the authorities in order to unify the whole nation and mobilize the mass.

The efforts of nationalists and later KMT government that made to construct the "humiliation memory" achieved a considerable success. The reputation of those imperialist countries, especially the Japan, had decreased drastically. The sense of humiliation and the hatred towards the Japanese imperialist among the public had been increasingly intense at that time. Apart from government's efforts, it is Japanese military's invasion of Manchurian, the north-east part of China, on $18^{\text {th }}$ September 1931, that made all Chinese people realized that there must be a war between China and Japanese invaders and it really arouse their patriotic sentiment. In order to motivate the citizens to prepare for the upcoming war, KMT government began to attach great importance to national humiliation education in primary and secondary schools. In 1932, the goal of historic education was revised by the government. The first goal was to grasp Chinese national history, especially the glories we enjoyed in the past and the humiliations we suffered recently. Aiming at inspiring the thinking of "cleansing the national humiliation", student must be told the reasons why we Chinese was invaded by the imperialist countries..$^{55}$

The textbook of primary schools in 1933 added the content like "history of the memorial of national humiliation". One of the paragraphs told the students:

At present, our unfortunate family has encountered a great number of robbers, who have been snatching our possessions, killing our families. Cannot you hear? There are plenty of weeping inside our family every day! In recent decades, we have been subjecting to imperialists aggressions and massacres all the time. Every day has become our national humiliation day... [E]specially in the recent two years, the atrocious Japanese has not only grabbed our countless lands and possessions, but also killed tens of thousands of our fellows. ${ }^{56}$

\footnotetext{
55 Liu, Yingjie. (Ed.) (2001). Zhongguo Jiaoyu Dashidian (1840-1949). Hangzhou: Zhejiang Jiaoyu Chubanshe, pp. 339-340.

$56 \mathrm{Gu}$, Lvtong (1933). Guochi jinianshi (History of the memorial of national humiliation), Shanghai: Xinzhongguo Chubanshe, pp.2-4.
} 
At the end of the paragraph, students were told to remember the atrocious Japanese, the robber, and always think about revenge.

Differing from the previous textbooks in Beiyang-governing era, which called Japan in a neutral way, for example, "atrocious Japanese" (Baori) began to be used to call Japan during KMT period. In addition, the proportion of the contents, which regarding the invasions of those imperialist countries, had changed. Although the first and second Opium War remiand important, atrocities of Japanese military had become the highlight of the textbooks, for example, the first Sino-Japanese War, the unequal treaty_-“Twenty-one Demands" and Japanese's invasion of the northeast China, etc. ${ }^{57}$

All in all, the victim narrative was a dominant theme in the pre-1949 era. During this period, the origins and popularization of "national humiliation" discourse was accompanied with the construction of a proper national identity, which was out of the clashes among the former Qing dynasty,warlords, and foreign countries. ${ }^{58}$ In fact, Chinese sense of humiliation was not brought by Japanese imperialist solely. However, the first establishment of the "National Humiliation Day", when Japan issued the ultimatum of the "Twenty-one Demand" on Chinese government, made Japan become a representative of those foreign imperialists. Furthermore, along with Japanese military's continuing steps of invading China, KMT government also took strong actions to construct Japan as a "national enemy" to motivate the population to prepare for the upcoming war. To sum up, the establishment of "National Humiliation Day" in the first half of 1900s and the upsurge of anti-Japanese sentiment associated with the intensification of national humiliation discourse together had contributed to shape Chinese's understanding of "humiliation" until Chinese Communist Party took over the country in 1949. In this sense, to most Chinese people at that time, Japan was the representative of the word "humiliation".

${ }^{57}$ Ibid.

58 Callahan, William A. (2006). "History, Identity, and Security: Producing and Consuming Nationalism in China," Critical Asian Studies, 38(02), p.179. 


\section{The Absence of Victim Narrative in China's Civil Society (1950s-1980s)}

From 1949 to the end of 1980s, victim discourse had totally disappeared in Chinese civil society. There was no new book published with the topic of "national humiliation" from 1947 to $1990 . .^{59}$ In accordance with the absence of victim narrative, the official emphasis on "atrocious Japan" had once disappeared in Chinese society during Mao's era. Although victim discourse was not the theme in the first four decades in People's Republic of China like before, situations in Maoist era (19491976) and Deng's era before 1989 were completely different. From Mao's perspective, China is a "victor" rather than a "victim". Chinese people's "Century of National Humiliation" had been cleansed by the achievements of defeating the Japanese invaders in 1945 and founding its own nation in 1949. The assertion of the CCP's role as an architect of Japan's surrender had dominated the whole country. From the late1970s to the late-1980s neither "victor narrative" nor "victim narrative" were used by the government to give the nation a new identity. Based on the "reform and opening up" policy, Chinese government had gradually changed from an idealist to a pragmatist whose top task was the development of the domestic economy. In this sense, Japan was neither a friend nor a foe.

\section{Victor discourse in the Maoist era and Japan as a "friend" (1949-the}

\section{late 1970s)}

It is the time that Mao Zedong stood on the Tiananmen Platform and told his people "Our Chinese has stood up", which symbolizes the end of the narrative of "Century of National Humiliation". Many scholars believe that the victim discourse disappeared in

\footnotetext{
59 According to the data from National Library of China. Quote in: Callahan, William A. (2006). "History, identity, and security: Producing and consuming nationalism in China," Critical Asian Studies, 38(2), p.186.
} 
Maoist years. Gries argues that victor narratives rather than victim narratives dominated China's civil society in Mao's period. In this scenario, the national independence was exclusively attributed to Chinese Communist Party. Its victory over the War of Resistance against Japan and the Civil War against KMT was considered as an imperative part of official historical narratives. ${ }^{60}$ According to Tyrene White, instead of fighting back to the imperialists, "mass mobilization" among classes in civil society was the main characteristic of the Maoist era. ${ }^{61}$ Zhao Suisheng in his article argues that there was a salience of nationalism from 1950s to the early 1970 s because of the promotion of official ideology-Marxism-Leninism and Mao Zedong Thought. ${ }^{62}$ Parks Coble points out that though Chinese people had just suffered from the war, "Maoist China lacked memorials, museums, and historical writing and literature devoted to the war" ${ }^{\prime \prime}$. Accompanied by the vanishing victim narrative, the emphasis on the "atrocious Japan" had once disappeared in Chinese society during Mao's era. In the following part, this article first tend to examine why the narrative of national humiliation had disappeared during Mao's era, and to be more specific, why the Communist government chose to avoid the sensitive "history issue" towards Japan at that time? Then, if the Communist government did not want to underscore the "bad" history between China and Japan, how it described the War of anti-Japanese without victim narrative? What kind of role did the Japanese assume in Mao's narrative?

In order to answer the first question that why there was oblivion of the War of Resistance against Japan during first few decades of new Communist China, it would be better to understand the new regime's position inside and outside. Domestically, the end of the Second Sino-Japanese War (1937-1945) did not leave a peaceful nor stable circumstance in China. In contrast, a civil war between the CCP and the KMT began in 1945 immediately. After five-year fighting, the Communist Party finally defeated the

\footnotetext{
${ }^{60}$ Gries, Peter H. (2005). "A Preliminary Analysis of Chinese Nationalism: The People, Their Pasts, and Their Passions," World Economics and Politics, 11, pp.45-46.

${ }^{61}$ White, Tyrene. (1990). "Post Revolutionary Mobilization in China: The One-Child Policy Reconsidered," World Politics, 43(1), p.55.

62 Zhao, Suisheng. (1998). "A State-Led Nationalism: The Patriotic Education Campaign in Post-Tiananmen China," Communist and Post-Communist Studies 31(3), p.288.

${ }_{63}$ Coble, Parks M. (2007). "China's 'New Remembering' of the Anti-Japanese War of Resistance, 1937-1945,” The China Quarterly, 190, p.395.
} 
Kuomin Party and then found the People Republic of China in 1949. Although the Communist Party established a new regime in mainland, the threat from the Taiwanbased KMT' Republic of China regime was still CCP's top concern. In this sense, the KMT rather than the Japanese military assumed the "other" character when Communist authority tried to construct a proper national identity in a new age. Similarly, instead of the War of Anti-Japanese, the Civil War between KMT and CCP had become the Communist China's daily narrative. According to CCP's new narrative of history, it is the party itself led the whole country to overcome the difficulties and defeat the Japanese military, the efforts of the KMT troops was neglected deliberately. Chiang Kai-shek, the top leader of the Republic of China, was described as a representative of Chinese landlords and bourgeoisie, as well as a "little brother" of the US imperialism by the Communist government. Due to Chiang Kai-shek and his party's nature, they were reluctant to fight against the Japanese invaders, and even "right up to 1944, Chiang Kai-shek never ceased his clandestine attempts to make peace with Japan." ${ }^{64}$ Compared with Chiang Kai-shek and his party, Japanese military was less important in Communists' narrative of history. Mao had criticized Chiang "adopted the reactionary policy of passivity and resisting Japan but actually opposing the Communists and the people." 65 According to this critique, though Japan was the common enemy of both CCP and KMT troops, the negative role of KMT rather than Japanese military was stressed by the Communist Party at that time. Internationally, apart from KMT, the US imperialist were another "enemy" for the new Communist regime. After 1949, another task of the CCP government was to counterbalance the US imperialist because of its supporting to the KMT-led Republic of China in Taiwan since the outbreak of the Korean War (1951).

Being conscious of great threats from the KMT-led regime and its US ally, the Communist government determined to anchor new China's national identity to communist ideology by stressing and defining the fundamental distinction between

\footnotetext{
${ }^{64}$ Mao Tse-tung (Zedong). (1954). The Policies, Measures, and Perspectives of Combating Japanese Invasion, Beijing: Foreign Languages Press, pp. i-ii.

65 Ibid.
} 
Communist China and the Capitalists "others". ${ }^{66}$ During Maoist period, social classed rather than the nation-state was considered as the primary category to define identity and security. From Mao's perspective, the nation-state was no longer a primary actor in the anarchic international structure. Mao argued "class differentiation transcends national boundaries, and opposing classes organize themselves based on transnational class identity and interests." ${ }^{67}$ Based on Mao's class-based viewpoint, it is not difficult to identify two "Others" of the Communist China. First, KMT and the landlord class it represented were the internal "Others", and second, the US imperialist, who assumed the leadership in the Capitalist Camp, was the external "others". As regard to Communist China's international position, it should be noticed that the communist China was not acknowledged by the international society as a legitimate regime until the year 1971. Facing the severe environments both inside and outside, the CCP authority had to take great efforts to magnify its role in national resistance war against Japan, condemned the role of KMT and US imperialist and downplayed the role of the Japanese military.

During the Communist Party first decades in power, KMT regime and the US imperialist had played the role as CCP's primary “enemies”. However, here are natural questions: what kind of role Japan assumed in PRC's narrative? How the communist regime saw the second Sino-Japanese War? In order to answer the first question, it tries to quote one of the public speeches of Mao in 1954 when met with Burma's premier. On this speech, Mao said “At present, Japan's position also changed, it has become a semi-occupied country, which is in his difficulty. Chinese people have no longer hatred Japan that much, instead, we hold a friendly attitude towards Japan."68 It is clear that the China's attitude towards Japan in the post-war era had changed dramatically. As we analyzed in the previous section, Japan was considered as a major "national enemy" who exerted humiliations on the Chinese. However, to Mao's mind, Japan was no

\footnotetext{
${ }^{66}$ Mitter, Rana. (2000). "Behind the Scenes at the Museum: Nationalism, History and Memory in the Beijing War of Resistance Museum," 1987-1997, The China Quarterly 161(1), p.283.

${ }^{67}$ Zhang, Tiejun. (2004). "Self-Identity Construction of the Present China," Comparative Strategy, 23(3): 281-301.

${ }^{68}$ Zhong, Zhicheng. (2006). Weile Shijie Gengmeihao: Jiang Zemin Chufang Shiji (Aiming at a more beautiful world), Beijing: ShijieZhishi Chubanshe, p.17.
} 
longer a previous invader, and it should be divided into two segments: Japanese military and Japanese people. Even though Japanese military had brought disasters to Chinese people, ordinary Japanese people were innocent, and to some extent, they were also the victim of Japanese militarists. Therefore, based on this division, Mao argued that Chinese people should treat Japanese people as our friend. A similar tone was also given by Premier Zhou Enlai, when he met with Japanese delegates in 1953:

The aggression of Japanese military not only made Chinese and Far East people had suffered considerable loss, but also brought an unparalleled disaster to Japanese people... Now Japanese people are struggling for national independence and fighting against re-militarism. Chinese people respect it. ${ }^{69}$

One year later, when Premier Zhou Enlai met with Japanese Diet members, he first expressed CCP's attitude towards the war. He said that though the history of the past 60 years of bilateral relations between China and Japan was not good, it was the thing of the past. Therefore, China and Japan should hope for the future but not the past. He also emphasized that China and Japan had thousand years of good relations, our generation just lived in the worst time unfortunately. ${ }^{70}$

In Maoist China, the government defined a clear line between mass Japanese people and a small handful of Japanese militarists. The former one was Chinese people's friends, who also suffered a lot due to the militarists, while the latter one was the only actor that should be blamed for the crime of the war. China's people/militarists division echoed Japanese conservative groups" "myth of the military clique" which "blamed a small group of military leaders for launching the war and asserted that the Japanese people were peace-loving, innocent victims of the war."71 In addition, this division was also compatible with Mao's class-based logic, the primary method to define national identity and security in Maoist China. In accordance with the class-based ideology, the anti-Japanese war was considered as an integral part of the

\footnotetext{
69 Zhou Enlai junshi wenxuan disiji (Zhou Enlai military thinking anthology Vol.4), Beijing: Remin Chubanshe. Retrieved on November 25, 2013, from: http://www.xiexingcun.com/zhouenlai/1-zeljswx599.htm 70 Zhou Enlai Nianpu 1954 (Annals of Zhou Enlai 1954). Retrieved on November 25, 2013, from:http://www.eywedu.org/zhouenlai13/054.htm

${ }^{71}$ He, Yinan. (2007). "Remembering and Forgetting the War: Elite Mythmaking, Mass Reaction, and SinoJapanese," History and Memory, 19(2), p.46
} 
struggle against the fascism at a global level. ${ }^{72}$

According to above Chinese top leaders' speeches, Japan, which was constituted of peaceful Japanese people, was no longer China's “enemy” but friend in Maoist China. As for the reason why the new communist government abolished negative narrative towards Japan in pre-1949 age, it was largely linked to the threats from the KMT and its US imperialist ally. Located in a severe environment, Beijing intended to draw Japan into its Communist Camp. If China could unite with Japanese Communist party as well as Japanese people to build a revolutionary frontline, it would erode the USled Camp against China. ${ }^{73}$ To meet this need, Chinese Communist government started "people's diplomacy" in allusion to Japan since the 1950s, aiming at undercutting Japan's security alliance with the United States. ${ }^{74}$ By the late 1960 s, international structure had changed dramatically with deteriorative Sino-Soviet relations and ameliorative Sino-US relations. These external changes required Chinese government to seek ways to collaborate with Japan to balance against the Soviet hegemony. Since the 1960s, Japan was topping a high strategic position in Mao's foreign policy. From Mao's perspective, keeping a good relationship with Japan would "contribute to the struggle against the US and the Soviet hegemonies, especially Soviet revisionism." ${ }^{.75}$ This could also be reflected in the beginning of the bilateral negotiation of diplomatic normalization in 1972. Overall, during the Maoist era, according to national external strategy, the narrative of the "atrocious Japan" had diapered.

With its powerful control of the social discourses, the CCP had easily institutionalized a new narrative of the war and history regarded as the exclusive national memory. The assertion of the Chinese Communist Party's role played as the architect of Japan's

\footnotetext{
72 Sneider, Daniel. (2013). "Textbooks and Patriotic Education: Wartime Memory Formation in China and Japan," Asia-Pacific Review 20(1), p.41.

73 Wang, Jisi. (1994). "International Relations Theory and the Study of Chinese Foreign Policy: A Chinese

Perspective," Thomas Robinson and David Shambaugh (Eds.), Chinese Foreign Policy: Theory and Practice, New York: Oxford University Press, pp.482-505.

${ }^{74}$ He, Yinan. (2007). "Remembering and Forgetting the War: Elite Mythmaking, Mass Reaction, and SinoJapanese," History and Memory, 19(2), p.47.

75 Jianguo Yilai Mao Zedong Wengao, no.13 (The Manuscripts of Mao Zedong Since the Founding of the Nation), Beijing: Zhongyang wenxian chubanshe, p.316.
} 
surrender had dominated the whole country. Contents of School textbooks, during Maoist period, were preoccupied with the civil war between CCP and the KMT, but focused very little on the Sino-Japanese War and Japanese crimes during the wartime. Moreover, the war, which had been considered as a national humiliation in pre-1949 era, was given the name of "The Great Chinese War of Resistance against Japanese Aggression" (Weida de Zhongguo Renmin Kangri Zhanzheng) in textbooks to coincide with the party's victor narrative. ${ }^{76}$ Besides, the former named like the "atrocious Japanese" (Baori) was replaced by the "Japanese imperialism" (Riben diguo zhuyi), "Japanese military" (Rijun) or the "Japanese bandits" (Rikou) ${ }^{77}$, which differentiate the small parts of bad Japanese from those of many good ordinary Japanese people.

Later during the Great Cultural Revolution (1966-1976), history education practically halted in schools throughout the entire country. "Red Classics"- the Revolutionary Operas (Yangbanxi) had dominated the social culture fields and served as the primary way to portrait the war and the Japanese for ten years long. With the very limited resources of entertainment and education at that time, the eight Model Operas nearly dominated the performance on stages, contents in radio broadcasts, and films on screens of the whole country. No exaggeration to say, they were the only available public entertainment for Chinese people, leading to a unique phenomenon in Mao's China "Eight hundred million people watched eight shows". ${ }^{78}$ Similar to the textbooks, Revolutionary Operas did not pay much attention to the topic of Japanese war crime. The anti-Japanese war just served under an ambiguous background, in which the Japanese army will definitely be defeated by the communist heroes at the end of those Operas. The reason to engineer such operas was to glorify the Chinese Communist Party, as well as the bravery of Chinese common people. Since the content of the traditional Peking Opera was no longer suitable to the new theme of the Maoist

\footnotetext{
${ }^{76}$ He, Yinan. (2007). "Remembering and Forgetting the War: Elite Mythmaking, Mass Reaction, and SinoJapanese," History and Memory, 19(2), p.48.

77 Ibid.

78 Clark, Paul. (2008). The Chinese Cultural Revolution: A History. Cambridge; New York: Cambridge University Press, p. 2.
} 
age — class struggle, new contents must be infused into this old form of art. ${ }^{79}$ There were eight famous Model Operas during that period, which include: The Legend of the Red Lantern, Shajiabang, Raid on the White Tiger Regiment, Taking Tiger Mountain by Strategy, Ode of the Dragon River, Red Detachment of Women, The White-Haired Girl and On the Dock. All these Operas were created to add the big significance to Chinese Communist Party and its army, while reduce importance of enemies. Moreover, among the above eight operas, only two of them were created based on the Second Sino-Japanese War, and five of the rest were derived from the domestic conflicts between different classes, the last one originated from the Korean War. In this sense, KMT, as a representative of the landlord class, along with its American ally still depicted as the perceived "enemy" during the revolutionary period, and the characteristic of Japanese soldiers as same as commanders were really cut-and-dried.

To sum up, in Maoist era, national humiliation discourse had totally disappeared from public eyes. Victor narrative rather than victim narrative had dominated China's civil society. In this scenario, the national independence was exclusively attributed to the Chinese Communist Party, it is the party itself which led the whole country to overcome the difficulties and defeat the Japanese military. Although there was no "national humiliation" at that time, two main "others"-KMT regime and the US, were defined hostile by the new communist regime. As a result, Japan's role as the "national enemy" was replaced by KMT and the US. According to Chinese top leaders' speeches in Maoist China, Japan was no longer China's "enemy” but a friend, and it was mostly due to the threats from KMT and the US imperialist. Being conscious of great threats of the KMT-led regime and its US ally, the Communist government determined to anchor new China's national identity to communist ideology and intended to ally Japan into its Communist Camp. In this sense, the mass good Japanese people were separated from those few bad militarists. To Mao's mind,

\footnotetext{
79 Mao characterized the traditional Peking Opera by "emperors, kings, generals, chancellors, wits, and beauties" (diwang jiangxiang caizi jiaren). Chen, Jin (1997), “Mao Zedong yu jingju gaige" ("Mao Zengdong and Peking Opera pevolution"), Dangshi tiandi, 6, p.25.
} 
ordinary Japanese were also took used by Japanese militarists. Therefore, based on this division, Mao argued that Chinese people should treat Japanese people as friends.

\section{A pragmatic China and Japan as a "partner" (1970s-1980s)}

After Mao's era, from the late-1970s to the late-1980s, neither "victor narrative" nor "victim narrative" were emphasized by the government to construct China's national identity. Looking back to this period, it is a transitional period from Mao's "victor narrative" to the "victim narrative" started in early-1990s. During the first decades after Maoist era, Deng Xiaoping's pragmatic philosophy had dominated the internal society. According to the implement of Deng's "reform and opening up" policy, Chinese government had gradually changed from an idealist to a pragmatist. The party, at that time, tried to get rid of the class-based ideology and made a sharp turnaround of its relationship with others in the world, which of course includes its adjacent neighbor-Japan. Ten-year Cultural Revolution had impoverished the country thoroughly; thus China's return to engagement in international society was driven by domestic reactions against this extreme activity. ${ }^{80}$ In 1977, the year after the end of the Cultural Revolution, China's Gross Productive Product (GDP) was just around 172 billion dollars, which merely accounted for $8.6 \%$ of American GDP. ${ }^{81}$ This reality pushed Deng to apply his pragmatic philosophy to China. One of his most famous slogans is: "It does not matter whether the cat is black or yellow, as long as it catches mice." 82 It means that consequences rather than methods or the process matters most important. To be more specific, in order to develop the domestic economy, China would overlook ideological factors intentionally when extend cooperation with other countries in economic area. Apart from the internal factors, external environment

\footnotetext{
${ }^{80}$ Buzan, Barry. (2010). “China in International Society: Is 'Peaceful Rise' Possible?” The Chinese Journal of International Politics.3, p.12.

${ }^{81}$ Statistics are from World DataBank, the World Band. Retrieved June 3, 2013 from: http://databank.worldbank.org/data/home.aspx

82 Deng Xiaoping wenxuan diyijuan(Deng Xiaoping, selected works Vol.1), Zenme huifu nongye shenchan (How to restore agricultural production), speech of 7 July 1962. Retrieved on December 27, 2013, from: http://news.xinhuanet.com/2011-04/24/c_121341795.htm.
} 
changed with the shrink of the Soviet Union's capability also enabled China to make this transformation.

The change of China's national identity required Chinese government to strengthen the Sino-Japanese relations in a more practical way. On August $12^{\text {th }}, 1978$, after six-year long fifteen-ground negotiation, the representatives of China and Japan finally signed the Treaty of Peace and Friendship, and two months later, Deng Xiaoping, Vice Premier of the P.R.C, was invited to visit Japan officially. On October 23 $3^{\text {rd }}$, 1978, the treaty went into effect ultimately. Deng considered this treaty as "it not only summarizes our previous relations in the matter of fact, but also at legal and political level, more importantly, it further confirms the value of developing the friendly relations between the two countries", "China and Japan should keep this friendly relation form generations to generations". ${ }^{83}$ After his visit, a modernized Japan had deeply rooted into Deng's mind. During that period, Japan was considered as a successful Asian case in modernization. Thus, Japanese style "offered lessons for China's struggle to shed traditional socialism without falling prey to individual capitalism." ${ }^{84}$ After getting rid of the Mao's class struggle approach and the socialist model of developing, China governed under Deng found that Japan's state-managing economy could be brought into in China. ${ }^{85}$ Therefore, for Chinese government, Japan was neither a real friend nor an enemy, but an important cooperative partner as well as a study model to China in its process of economic development. Actually, after over ten years' communication and cooperation with Japan, this view was genuinely accepted by the public. A national survey conducted in 1989 demonstrated that the exchange of science and technology and economic cooperation were the most important parts of Sino-Japanese relations in the mind of Chinese people. ${ }^{86}$ In the

\footnotetext{
83 Deng Xiaoping Xuexi Gangyao (Study Outline of Deng Xiaoping's Diplomatic Thoughts), Beijing: Xinshijie Chubanshe, p.141.

84 Rozman, Gilbert. (2002). "China's changing images of Japan, 1989-2001: the struggle to balance partnership and rivalry," Internal Relations of Asian-Pacific, 2(1), p.99.

85 Xiao, Yong. (1992). "Riben de jingyanyuzhongguo de gaige" (Japan's experience and china's reform ), Japanese Studies, 5: 110-113.

86 There were $69.3 \%$ of Chinese respondents considered that the exchange of science and technology was the most important topic in Sino-Japanese relations, while $66.2 \%$ chose the economic cooperation. See Jiang, Lifeng. (1989). "Zhongri lianhe jinxing de shehui yulun diaocha shuomingle shenme" ("What Can the Result of the Joint Survey of Public Views Tell Us"), Riben wenti ziliao, 2, p.24.
} 
context of "reform and open door" policy, Japan, to a great extent, was taken as a role model for China's development.

According to some articles, which focus on Sino-Japanese relations, China's attitude and narrative towards Japan had already changed in the early-1980s. ${ }^{87}$ Among them, He argues that the controversy of Japanese textbook publicized in 1982 is a good example to reveal the internal divergence of the party between the reformists and the conservatives. This inner pressure led Deng has to compromise with the conservatives with regard to this textbook issue. As a result, Japan has become an immoral "others" again in the party's discourse since then.$^{88}$ Coble points out that the waning appeal to ideology of Marxism-Leninism and the changing attitude of Taiwan's strategic position induced a "New Remembering" of the Sino-Japanese war from the mid1980s to the mid-1990s. ${ }^{89}$ However, in Coble's article, there is insufficient evidence to show that the second Sino-Japanese War reappeared again in public at that time. ${ }^{90}$ Differing form Coble, Reilly argues, it is the change of the external factors including China's rapprochement with the Soviet Union and the expanding military capacity of Japan that brought the wartime suffering back to the national discourse of history. ${ }^{91}$ This thesis keeps the opinion of that it was not until the happening of Tiananmen Incident in 1989 did the Communist China change its narrative on the "history issues" between China and Japan. This argument can be supported by the government's lowkey reactions to the controversy about Japanese textbook in 1982 and three Japanese Premier's worship at the Yasukuni Shrine in 1975, 1982 and 1985 respectively. ${ }^{92}$

The "Japanese Textbook Incident" was a consequence of long-term conflict between

\footnotetext{
${ }^{87}$ He, Yinan. (2007). "Remembering and Forgetting the War: Elite Mythmaking, Mass Reaction, and SinoJapanese," History and Memory, 19(2): 43-74; Reilly, James. (2011). "Remember History, Not Hatred: Collective Remembrance of China's War of Resistance to Japan," Modern Asian Studies, 45(2): 463-490; Coble, Parks M. (2007). “China's 'New Remembering' of the Anti-Japanese War of Resistance, 1937-1945," The China Quarterly, 190: 394-410.

${ }_{88}$ He, Yinan. (2007). "Remembering and Forgetting the War: Elite Mythmaking, Mass Reaction, and SinoJapanese," History and Memory, 19(2): 52-54.

${ }_{89}$ Coble, Parks M. (2007). "China's 'New Remembering' of the Anti-Japanese War of Resistance, 1937-1945," The China Quarterly,190: 402-406..

${ }_{90}$ Cobles did provided considerable evidence that the role of the KMT forces was acknowledged in academic field.

91 Reilly, James. (2011). "Remember History, Not Hatred: Collective Remembrance of China's War of Resistance to Japan," Modern Asian Studies, 45(2), p.471.

92 "Canbai jingguo shenshe de lidai riben shouxiang" ("Japanese premiers' worship at Yasukuni Shrine in the past”), Hexun News. Retrieved on November 20, 2013, from: http://news.hexun.com/2013-12-27/160969655.html.
} 
the progressive academic establishment and the right-leaning conservative establishment. ${ }^{93}$ After Japan's surrender, the narrative of the history was dominated by those progressive scholars for quite a long time until launching of "Biased Textbook Campaign" (Henkō Kyokkasho Kyanpein $)^{94}$ by the conservative establishment around 1980. By criticizing the existing communist-oriented view in textbooks as well as an absence of the Japanese view of History, Education Minister Tanaka Tatsuo reminded those textbook editors to attach more importance on patriotism and "soften their approach to Japan's excesses" during the wartime. ${ }^{95}$ In the middle-1982, the Ministry of Education (MoE) was reported to issue a statement of textbook "whitewashing". For example, the ambiguous description of the Nanjing Massacre in the Nihon Shoseki textbook, it only mentioned "killings of numerous civilians including women and children in the "chaos of occupation" without the raping crime. ${ }^{96}$ Although Chinese government had given a formal protest to Tokyo, there is still a phenomenon that Beijing did not respond to this textbook incident immediately. The state-run newspaper Renminribao (People's Daily) started to Lash out Japanese government's provocative behavior on $20^{\text {th }}$ July 1982 after one-month waiting. ${ }^{97}$

This subtle delay in some degree showed that Deng and his fellows of reformism worried about destroying the recovering Sino-Japanese relations. Moreover, Chinese government did not revise its own textbook as a counterattack to Japan. ${ }^{98}$ When Japanese Premier Suzuki Zenko visited China on $28^{\text {th }}$ September 1982, Deng Xiaoping just expressed his concern on Japanese new trend of militarism. Deng said "there must be other issues like this textbook controversy in the future between China and

\footnotetext{
93 Bukh, Alexander. (2007). "Japan's History Textbooks Debate: National Identity in Narratives of Victimhood and Victimization," Asian Survey, 47(5), p.684.

94 He, Yinan. (2007). "Remembering and Forgetting the War: Elite Mythmaking, Mass Reaction, and SinoJapanese," History and Memory, 19(2), p.53.

95 Rose, Caroline. (1998). Interpreting History in Sino-Japanese Relations: A Case Study in Political DecisionMaking, New York: Routledge, pp. 68-71.

96 Kodama, Chugaku, p. 258. Quoted from: Bukh, Alexander. (2007), "Japan's History Textbooks Debate: National Identity in Narratives of Victimhood and Victimization," Asian Survey, 47(5), p.694.

${ }_{97}$ Retrieved on November 27, 2013, from: http://www.nongli.com/today/todayxx-2622.htm.

98 There is a huge difference between the government reactions to the textbook controversy between China and Japan occurred in 1982 and the early 2000 respectively. For the latter one, the government reacted by revising Chinese history textbook to replace the 1990 s version.
} 
Japan...With regard to Sino-Japanese political relations, we hope you and your government as well as Japanese future governments to be wary of militarism." 99 As a result, the controversy about Japanese textbook only received a "warning" from Chinese government of no any anti-Japanese reactions from the public, which is in contrast with a similar "textbook controversy" between China and Japan occurred in 2005. Similarly, Japanese Premier's worship at the Yasukuni Shrine in 1970s and 1980s neither triggered a high-profile wide critique from the government, nor caused large scale of reactions of anti-Japanese nationalism. In October 1985, just two months after Japanese Premier Nakasone Yasuhiro's worship at Yasukuni Shrine, People's daily used a full-page article to give an optimistic view on Sino-Japanese relations. ${ }^{100}$

Due to China's "reform and opening-up" policy, the era of 1980s witnessed a peak of Sino-Japanese relationship development in aspects of politic, economic and culture, especially in politic. Regard to political relations, top-level visits between Chinese and Japanese leaders became more frequent during this period. The most distinctive feature of Sino-Japanese relations in 1980s was that top leaders in both China and Japan had realized the significant meaning of establishing a cooperative and reciprocal bilateral relation for each side. As a result, because of the efforts made by the high-level politicians, a kind Sino-Japanese relation could be reflected by increasing frequent visits of political exchange.

After signing of the Peace and Friendship Treaty in 1978, Japanese Premier Ohira Masayoshi visited China In December 1979 before long. During this diplomatic visit, Premier Ohira agreed with cooperation toward China on six financial programs for its demand, and decided to provide Chinese government with 3,009 billion yen's loan. ${ }^{101}$ The visit of Ohira started a boom of top-level exchange visits between these two

\footnotetext{
99 Deng Xiaoping Sixiang Nianpu, 1975-1997, (Annals of Deng Xiaoping's Thoughts, 1975-1997), Beingjing: Zhongyang Wenxian Chubanshe.

100 Reminribao (People's Daily), (October 29), p.2. Quote from: Rozman, Gilbert. (2002). "China's changing images of Japan, 1989-2001: the struggle to balance partnership and rivalry," Internal Relations of Asian-Pacific, 2(1), p.98.

101 Huang, Dahui. (2008). "Zhongguo gaige kaifang sanshinian yu zhongri guanxi" ("30 years of development in Sino-Japanese relations"), Jiaoxue yu yanjiu, 11, pp.17-18. And it is worth mentioning that Japan is the first country that offered government loan to China.
} 
countries. The following table shows all visits between leaders of China and Japan from 1978 to $2013 .{ }^{102}$ According to the table, there were eleven times top-level visits paid by Chinese and Japanese leaders during the period from 1978 to 1989. Official top-level visits during these fifteen years account for nearly half of total visit in two countries throughout their whole diplomatic history from 1978 to $2013 .{ }^{103}$ These frequent diplomatic visits show that the communication channel for top-level politicians was unblocked. Good relationship between China and Japan not only determined by the number of top-level political visits, but also by the themes of the meetings between two sides. When Chinese premier Zhao Ziyang paid a visit to Japan in May 1982, "Three Principle of Sino-Japanese Relations"- items to be peaceful and friendly, mutually beneficial and long-term stable, were raised to confirm and promote the bilateral relations.

\begin{tabular}{|c|c|c|}
\hline Year & Japanese leader's visits to China & Chinese leader's visits to Japan \\
\hline 1979 & $\begin{array}{l}5^{\text {th }} \text { December, Premier Ohira } \\
\text { Masayoshi visited China. }{ }^{104}\end{array}$ & $\begin{array}{l}6^{\text {th }} \text { February, Vice Premier Deng Xiaoping } \\
\text { had a brief visit to Japan on his way back } \\
\text { China from the US. }\end{array}$ \\
\hline 1980 & & $\begin{array}{l}\text { 27 } 7^{\text {th }} \text { May, Premier Hua Guofeng visited } \\
\text { Japan. } 105\end{array}$ \\
\hline 1982 & $\begin{array}{l}26^{\text {th }} \text { September } \\
\text { Premier Suzuki Zenko visited China. }\end{array}$ & $\begin{array}{l}31^{\text {st }} \text { May, } \\
\text { Premier Zhao Ziyang visited Japan. }{ }^{106}\end{array}$ \\
\hline 1983 & & $\begin{array}{l}23^{\text {rd }} \text { November, President Hu Yaobang } \\
\text { visited Japan. }{ }^{107}\end{array}$ \\
\hline 1984 & $\begin{array}{l}\text { 23 }{ }^{\text {rd }} \text { March, Premier Nakasone } \\
\text { Yasuhiro visited China. }{ }^{108}\end{array}$ & \\
\hline 1985 & & $\begin{array}{l}21^{\text {st }} \text { April, Peng Zhen, Chairman of the } \\
\text { Standing Committee of the National } \\
\text { People's Congress, visited Japan. }\end{array}$ \\
\hline
\end{tabular}

\footnotetext{
102 Summarized from the data from Ministry of Foreign Affairs of the People's Republic of China, retrieved on November 21, 2013, from: http://www.fmprc.gov.cn/mfa_chn/gjhdq_603914/gj_603916/yz_603918/1206_604546/sbgx_604550/ 103 Since 1978, there are totally 23 times of top-level visits between China and Japan. See table 1.

104 During this visit, Japan provided China with the first government loan.

105 It is the first time Chinese Premier visit Japan. Hua also participated in the funeral of Premier Ohira Masayoshi on 8th July the same year.

106 Zhao raised the "Three Principle of Sino-Japanese relations" during his visit.

107 During this visit, Hu confirmed the "Four Principle of Sino-Japanese relations" with Japanese premier Nakasone Yasuhiro, and decided to build "China-Japan Friendship Committee for the $21^{\text {st }}$ Century".

108 Japan provided China with the second government loan.
} 


\begin{tabular}{|c|c|c|}
\hline 1986 & $\begin{array}{l}8^{\text {th }} \text { November, Premier Nakasone } \\
\text { Yasuhiro's second visit to China. }\end{array}$ & \\
\hline 1988 & $\begin{array}{l}25^{\text {th }} \text { August, Premier Takeshita } \\
\text { Noboru visit China. }{ }^{109}\end{array}$ & \\
\hline 1989 & & $12^{\text {th }}$ April, Premier Li Peng visited Japan. \\
\hline 1991 & $\begin{array}{l}10^{\text {th }} \text { August, Premier Kaifu Toshiki } \\
\text { visit China. }{ }^{110}\end{array}$ & \\
\hline 1992 & $\begin{array}{l}23^{\text {rd }} \text { October, Emperor Akihito } \\
\text { visited China. }\end{array}$ & $\begin{array}{l}6^{\text {th }} \text { April, President Jiang Zemin visited } \\
\text { Japan. }\end{array}$ \\
\hline 1994 & $\begin{array}{l}19^{\text {th }} \text { March, Japanese Premier } \\
\text { Hosokawa Morihiro visited China. }\end{array}$ & $\begin{array}{l}23^{\text {rd }} \text { February, Premier Zhu Rongji visited } \\
\text { Japan. }\end{array}$ \\
\hline 1995 & $\begin{array}{l}2^{\text {nd }} \text { May, Japanese Premier } \\
\text { Murayama Tomiichi visited China. }\end{array}$ & \\
\hline 1998 & & $\begin{array}{l}25^{\text {th }} \text { November, Premier Jiang Zemin visited } \\
\text { Japan. }\end{array}$ \\
\hline 1999 & $\begin{array}{l}8^{\text {th }} \text { July, Japanese Premier Obuchi } \\
\text { Keizo visited China. }\end{array}$ & \\
\hline 2000 & & $\begin{array}{l}12^{\text {th }} \text { October, Chinese Premier Zhu Rongji } \\
\text { visited Japan. }\end{array}$ \\
\hline 2006 & $\begin{array}{l}\text { 8th October, Japanese Premier Abe } \\
\text { Shinzo visited China. }\end{array}$ & \\
\hline 2007 & & $11^{\text {th }}$ April, Premier Wen Jiabao visited Japan. \\
\hline 2008 & & $6^{\text {th }}$ June, President Hu Jintao visited Japan. \\
\hline
\end{tabular}

In economic aspect, China-Japan relations on trade had stepped into a new phase from1978. In 1981, just two years after the normalization of Sino-Japanese relations, the total trading amount between China and Japan had increased from 4.8 billion dollars to 10.3 billion dollars. In 1985, Japan had become largest trading partner of China with trade volume of nearly 20 billion-dollar, more specifically, 24\% of gross import and $30 \%$ of gross export of China were from the trading with Japan. ${ }^{112}$ The bilateral trade volume had reached 25.4 billion dollars in 1992. ${ }^{113}$ Apart from the increasing trading volume between China and Japan, good economic relations between China and Japan could also be reflected by Japanese government's ODA (Official

\footnotetext{
109 During this visit, Japan provided China with the third government loan.

$110 \mathrm{He}$ is the first foreign leader visited China after 1989 incident.

111 It is the first and only time that Japanese emperor visited China.

112 Huang, Zemin. (1997). "Xunsu fazhan de zhongri maoyi guanxi" ("Rapid development of Sino-Japanese trade relations”), International Survey, 4, p.11-12.

113 Ibid.
} 
Development Assistance) to China. During visit paid by Japanese Premier Ohira Masayoshi's in 1979, Japan decided to provide China with 3,309 billion yen's government loan from 1979 to 1983, which opened the prelude of Japanese government ODA to Chinese government. Since then, the ODA had been an integral part of bilateral economic cooperation between China and Japan, and even a symbol of one friendly Sino-Japanese relationship until the end of it in 2008. Overall, there are four installments of ODA from Japan to China, and three of them were signed during this honeymoon. ${ }^{114}$

In terms of cultural relations, no matter what kind of exchange between China and Japan, government or non-government, would afford a great amount of opportunity to develop in 1980s based on good political and economic relations. On December $6^{\text {th }}$, 1979, China and Japan signed a cultural exchange agreement, which propelled SinoJapanese cultural communication to a higher level. This agreement encouraged both sides to cooperate in the following fields: academic exchanges, education, joint researches, cultural activities, media and publication. ${ }^{115}$ In the academic field, the number of Chinese delegations reached 250 only in the year of $1981 .{ }^{116}$ Up to 1991 , the numbers of mutual visits between the two countries had reached 540 thousand, which was 55 times to the number in 1972 when China and Japan normalizing their bilateral relations. ${ }^{117}$ Meanwhile, there had been 127 couples of sister cities between China and Japan until 1991, which account more than half of the total amount of Sino-

\footnotetext{
114 The first installment ODA (1979-1983) was promised by Premier Ohira Masayoshi when he visited China in 1979. This 3,309 billion yen's government loan included 2,009 billion yen's program loan, which mainly focus on the construction of transportation and electrical power, and the other 1,300 billion yen's commodity loan used for other programs. The second installment ODA (1984-1989) was promised during the term of office of Premier Suzuki Zenko's. The second ODA from Japan provided China with 4,700 billion yen's government loan, which covered 16 programs. The third installment ODA (1990-1995) was confirmed during Premier Takeshita Noboru's visit to China in 1988. The third Japanese ODA offered China 8,100 billion yen's on 42 constructive programs, which includes: electrical power, railways, ports, communications, urban infrastructure, etc. (See Cheng, Yongming\& Shi, Baoqi. (2005). Zhongri jingmao guanxi liushimian (Sino-Japanese Economic and Trade relations in 60 Years), Tianjin: Tianjin Sehui Kexueyuan Chubanshe, pp.320-321.)

115 "Zhonghua renmin gongheguo he riben zhengfu weicujin wenhua jiaoliu de xieding" ("Agreements between China and Japan to promote Cultural Exchanges"), Xihua.net. Retried on December 2, 2013, from: http://news.xinhuanet.com/ziliao/2002-03/26/content 331611.htm

${ }^{116}$ Lin, Delian. (1990). Dangdai zhongri guanxishi (Contemporary relations between China and Japan), Beijing: Zhongguo duiwai jingji maoyi Chubanshe, p.182.

117 Huang, Dahui. (2008). "Zhongguo gaige kaifang sanshinian yu zhongri guanxi" ("30 Years of development in Sino-Japanese relations"), Jiaoxиe уи Yanjiu, 11, p.17.
} 
Japanese sister cities at present. ${ }^{118}$ It is also worth mentioning that 3,000 Japanese youth delegates were invited by Chinese government in $1984 .{ }^{119}$ This is the largest and the largest-scale and the most influential social exchange led by the government in Sino-Japanese history.

During this period, achievements of good relationship between China and Japan enjoyed both by governments and ordinary people. Since the normalization of diplomatic relations, the public views on each other had been heading positive side until the early-1990s. A public survey conducted by a shanghai Journal in 1978 showed that among 2,500 Chinese people in forty cities, Japan enjoyed the title as the most welcomed country with $31.4 \%$ of the respondents' supports, which was nearly doubles the figure of the no.2-Western Europe. In contrast, the US and the Soviet Union were the most unpopular countries in China. ${ }^{120}$ A similar conclusion was given by a joint survey conducted by Ribenwentiziliao and Yomiuri shimbun in May, 1989 before Tiananmen Incident. According to this survey, over half of the respondents on both sides hold a positive view on Sino-Japanese relations, and only $9.2 \%$ of Chinese respondents and $11.6 \%$ of Japanese respondents considered the relations are bad. Regard to the prospect of the bilateral relations, $88.5 \%$ of Chinese respondents hold an optimistic view on bilateral relations and believed that China and Japan should be closer in next decennium. Besides, over $50 \%$ respondents got a feel of affinity with Japan, while in adverse figure of Japan, it was over $70 \%$. The most impressive result of this joint survey was the part about "history issue". When asked the question like "Do you think Japan had reproached itself for its past aggression", 56.7\% of Chinese people chose to answer "yes", which was higher than Japanese side (54.6\%). ${ }^{121}$

\footnotetext{
118 The total number of sister cites between China and Japan are 251till 2013. Retrieved on December 3, 2013, from: http://japan.people.com.cn/95917/8293960.html

119 On National day of that year, all these Japanese delegates were given a sit on the viewing standing of Tiananmen to see military parade, which was the first time since the end of Cultural Revolution. After the parade, there was a dancing ball held in Tiananmen Square for Chinese and Japanese young people until midnight. See "Jiyi 1984: Zhongri qingnian Tiananmen gongwu de rizl" ("Remembrance 1984: the days of Chinese and Japanese youth dancing together in Tiananmen”), (May 5,2008), Dongfang Zaobao. Retrieved on Decenmber 3 ,2013 from: http://epaper.dfdaily.com/dfzb/html/2008-05/05/content 54929.htm.

120 Rozman, Gilbert. (2002). "China's changing images of Japan, 1989-2001: the struggle to balance partnership and rivalry," Internal Relations of Asian-Pacific, 2(1), p.98.

121 Jiang, Lifeng. (1989). "Zhongri lianhe jinxing de shehui yulun diaocha shuomingle shenme" ("What can the result of the joint survey of public views tell us"), Riben wenti ziliao, 2: 22-25.
} 
According to this survey, as least, till the end of 1980s, it can be concluded that the majority of Chinese people had forgiven Japan for what it did during the wartime, and most Japanese people still felt guilty to China so that the impact of "history issue" to Sino-Japanese relations was weakening. All in all, During the 1980s, positive views on each other reached its peak in China-Japan post-war history, which means that Japan was no longer the "national enemy" but had become a reliable partner to China in this period.

To sum up, from the late-1970s to the late-1980s, China was neither a "victor" nor a "victim", but a pragmatic actor who dedicated to get rid of the class-based ideology and focus on domestic economic development. It made a sharp turnaround in its relationship with other countries in the world. The change of China's national identity required Chinese government to develop the Sino-Japanese relations from a more practical perspective. Japan, at that time, was neither a real friend nor an enemy, but an important cooperative partner as well as a study model for China in its process of economic development. In order to maintain a good relations with Japan, Chinese government kept a low profile responding to some sensitive history issues, for example, the controversy about Japanese textbook in 1982 and three Japanese Premier's worship at the Yasukuni Shrine during this time. Because of government's moderate attitudes toward "history issues" and its pragmatic approach to Japan, the 1980s saw a peak of Sino-Japanese relationship. Besides, good relationship between China and Japan was also shared by ordinary people of these two countries. In 1980s, Chinese people's views on Japan also reached its peak. Based on the attitudes of both Chinese government and the public towards Japan, the "bad history" seemed to be no longer an obstacle of the future development of Sino-Japanese relation. Yet, when the spring of 1989 came, everything was changed. 


\section{The Revival of Victim Discourse since the Late-1980s}

On the eve of 1990s, the CCP was facing a huge "ideology vacuum”. When Deng's reform encountered a hardship of high inflation and higher unemployment rate, his pragmatic philosophy lost its supporting drive. Since the old ideology in Mao's era had been replaced by Deng's practical slogans, there was no dominant ideology inside the country can be used to inspire people effectively overcoming the hard time. This "ideology vacuum" later gave rise to the well-known anti-government demonstration in Tiananmen Square. After Tiananmen Incident, Deng began to readjust his previous strategy, and decided to give more emphasis on ideological education. Soon after in 1989, the "Patriotic Education Campaign" was launched by the Party. Since then, the "Century of National Humiliation" discourse thus was put up again by the government to legitimize its rules and overcome the regime crises. It should be noted that the initial objective of this "Patriotic Education Campaign" was to unify the nation rather than create a new indignation towards Japan. However, in order to make this campaign more effective, a typical "other" was needed to encourage Chinese strong patriotism and nationalism. Since "the horrors of the Japanese invasion were painfully clear", ${ }^{122}$ the emphasis on the war history had made Japan regain its role as a "national enemy" of China. As a result, the patriotic campaign got a success in stimulating public resonance.

\section{"Patriotic Education Campaign" and a changing image of Japan (since the early 1990s)}

After the Cultural Revolution, Deng Xiaoping started the economic reform in China. In order to eradicate the old ideology in Mao's era, Deng replaced it with a new pragmatic one- "to get rich". Unfortunately, the reform encountered a hardship with

\footnotetext{
122 Reilly, James. (2011). "Remember History, Not Hatred: Collective Remembrance of China's War of Resistance to Japan," Modern Asian Studies, 45(2), p.471.
} 
high inflation and higher unemployment rate in the late 1980s. At that moment, since the old ideology Marxism-Leninism and Mao Zedong Thought had been replaced by practical slogans, there was no dominant ideology inside the country to inspire people effectively overcoming the hard time. The CCP had faced the most severe political challenge_- "three belief crises"123 — since 1949. This "ideology vacuum" gave rise to appearance of western liberal values among Chinese young people in the late 1980, and then led to the well-known anti-government demonstration in Tiananmen Square. ${ }^{124}$ After controversial suppression of the student demonstration, Deng began to reflect on his previous strategy. He concluded that the biggest mistake of the Party was that they ignored the importance of ideological education. He admitted that:

I have told foreign guests that, during the last 10 years, our biggest mistake was made in the field of education, primarily in ideological and political education — not just of students but of the people in general. We did not tell them enough about the need for the hard struggle, about what China was like in the old days and what kind of a country it was to become. ${ }^{125}$

The lesson about "Tiananmen Incident" taught Deng and his successor of country power; Jiang Zemin that ideological and political education should be indoctrinated seriously to the younger generation as soon as possible. As Paul Cohen said, after the Tiananmen Incident, "there was a felt, if unstated, need on the part of the Chinese government to come up with a new legitimating ideology to burnish the rapidly dimming luster of the original Marxist-Leninist-Maoist vision. The logical candidate, was nationalism, to be inculcated via a multifaceted program of patriotic education."126 Soon after 1989, the "Patriotic Education Campaign" was launched by the Party around the whole country. The main content of the patriotic education was to tell young people the humiliating experience that China has suffered in the fight

\footnotetext{
123 They are crisis of faith in socialism, crisis of belief in Marxism, and crisis of trust in the party. See Chen, Jie. (1995). "The Impact of Reform on the Party and Ideology in China," Journal of Contemporary China 9: 22-34. 124 Zhao, Suisheng. (1998). "A State-Led Nationalism: The Patriotic Education Campaign in Post-Tiananmen China," Communist and Post-Communist Studies, 31(3), pp.288-289.

125 Deng Xiaoping wen xuan disanjuan (Deng Xiaoping, selected works Vol. 3) "Zaijiejian shoudu jieyan budui junyishang ganbushi de jianghua" ("Address to officers at the rank of general and above in command of the troops enforcing martial law in Beijing”), speech of 9 June 1989. Retrieved on October 2, 2013, from:http://www.china.com.cn/zhuanti2005/txt/2004-08/02/content_5625194.htm.

126 Cohen, Paul A. (2003). China Unbound: Evolving Perspectives on the Chinese Past, London: Routledge Curzon, p. 167.
} 
against West and Japanese invasion. Thus, the "Century of National Humiliation" discourse thus was rediscovered by the government to legitimize its rules and overcome the regime crises.

The "Patriotic Education Campaign" was launched by Jiang Zemin in 1991 related two important official documents. The first one was "Notice about Conducting Education of Patriotism and Revolutionary Tradition by Exploiting Extensively Cultural Relics" (Notice) issued by CCP Central Committee and the second was "General Outline on Strengthening Education on Chinese Modern and Contemporary History and National Conditions" (General Outline) issued by Ministry of Education respectively. ${ }^{127}$ The "General Outline" stressed that the patriotic education should be carried out to all primary and high schools, which includes: make sure that all schools have a the flag-raising ceremony every week, editing and publishing the patriotic books and comic books, and conducting the patriotic education with Chinese humiliating history. ${ }^{128}$ It deserved noticing that Jiang wrote a letter himself to the Education Minister to address the urgency of the patriotic education. Jiang said in his letter, which public in People's Daily on March 9, 1991 going as that:

We should conduct education on Chinese modern and contemporary history and national conditions to pupils (even to the kids in kindergarten), middle school students and to the university students. The education should go from the easy to the difficult, and should be persistent. ${ }^{129}$

The introduction of Beijing quickly conveyed to local governments and institutions. As nearly all of schools in China, from primary level to the highest one, scare under the control of the central government, it would be efficient for the whole intact system to implement these two important documents. The "General Outline" particularly required that all schools should take actions less than three years to follow the

\footnotetext{
127 Wang, Zheng. (2008). "National Humiliation, History Education, and the Politics of Historical Memory: Patriotic Education Campaign in China," International Studies Quarterly, 52, p.789.

128 "Guojia Jiaowei 1991nian Gongzuo Yaodian" ("General Outline on Strengthening Education on Chinese Modern and Contemporary History and National Conditions"). Retrieved on October 2, 2013, from: http://www.moe.edu.cn/publicfiles/business/htmlfiles/moe/moe_164/200408/3440.html. 129 Ibid.
} 
instruction and reform the curriculum. In 1994, another official document "Outline on Implementing Patriotic Education", which issued by the CCP Central Committee, symbolized the addition of full-scale implement to patriotic education. This outline stressed that patriotism is the "spiritual pillar" of all Chinese people, and confirmed the content of patriotic education, in which historical humiliation education was given a great importance. ${ }^{130}$ As Callahan comments, the primary goal of this patriotic education campaign is "to reeducate the youth (as it was in the past), as to redirect protest toward the foreigner as an enemy, as an external 'other'". ${ }^{131}$

Since the early 1990, the narrative of the "Century of National Humiliation" has been emphasized in all aspects, especially the state education system. Many scholars agree with the argument for the history textbooks play an essential role in constructing and reproducing national narratives. According to Howard Mehlinger, textbooks are tools to teach young people "what adults believe they should know about their own culture, as well as that of other societies." 132 Elie Podeh points out that a national education system applied as the effect of textbooks should be considered as a primary instrument for socializing young generation to the dominant values. They are the "agents of memory" whose tasks were to interpret the "true" common memories adopted by younger generations, and finally let them accept this shared value for granted. ${ }^{133}$ In the scenario of China, the extending of education system and the adoption of these kind of textbooks should pay more attention because there is only one set of textbooks authorized by the government. In addition, it deserved to notice that the content of the uniform college-preparatory examination is based on this set of textbooks, no one dare use the alternative if they want to pass and even get a good grade in this crucial examination.

\footnotetext{
130 “Aiguo zhuyi jiaoyu shishi gngyao" ("Outline on Implementing Patriotic Education”), Ministry of Education of the People's Republic of China, Rednet, 2008. Retrieved ON October 2, 2013, from: http://hn.rednet.cn/c/2008/06/30/1539945.htm.

131 Callahan, William A. (2006). "History, Identity and Security: Producing and Consuming Nationalism in China," Critical Asian Studies, 38 (2): 179-208.

132 Mehlinger, Howard D. (1985). "International Textbook Revision: Examples From the United States," Internationale Schulbuchforschung, 7, p.287.

133 Podeh, Elie. (2000). "History and Memory in the Israeli Educational System: The Portrayal of the Arab-Israeli Conflict in History Textbooks (1948-2000)," History and Memory, 12 (1), p.66.
} 
The new version of Chinese contemporary and modern history textbooks was published in the early 1990s. The revised textbooks according to the instruction of the "Patriotic Education Campaign" showed a shifting nature of the narrative in Chinese history. First, the revised textbooks of Chinese contemporary and modern history start from the Opium war (1840-1842), which symbolizes the beginning of the "Century of National Humiliation". On one hand, in this new kind of version, the history of suffering starting from those immoral invasions of foreign imperialists was reemphasized, for example, the War of Resistance of Japanese (1937-1945). On the other hand, some external conflicts among China and other countries, for example, the War against Vietnam (1979) was deleted in history textbooks. ${ }^{134}$ Second, the revised textbooks divided the wartime into two sections. The first section was about the confrontation between $\mathrm{CCP}$ and KMT while the second part mainly focuses on the Second Sino-Japanese War. Differing from Mao's age, in the version of 1990s version, KMT's contribution of resistance against Japan was acknowledged. When facing foreign invaders, CCP and KMT put aside their differences and fought together against Japanese troops or sometimes on their own ways.

To be more specific, according to this new version, the "other" of the nation has changed from KMT and the landlord class to the foreign invaders, especially Japan. In the early 2000s, because of the annual visits made by Japanese Prime Minster Koizumi's to the Yasukuni Shrine and the approval of Japanese government about the use of history textbook edited by right-wing scholars, Chinese government decided to revise its own history textbook again. By 2004, this latest version had gradually replaced the 1990s version. This latest one keeps focusing on China's victim character in front of the criminal and brutal invader-Japan, and Chinese Communist Party's indispensable role in defeating the Japanese. ${ }^{135}$ Compared to former versions, it gives Nanjing Massacre more weight throughout narration of

\footnotetext{
134 According to a public survey in 1987, Vietnam ranked the first in the question of "which country do you think has posed threat to China's national security" with $52.7 \%$ of support, while Japan only chosen by $18.9 \%$ of Chinese respondents. Jiang, Lifeng. (1989). "Zhongri lianhe jinxing de shehui yulun diaocha shuomingle shenme" ("What can the result of the joint survey of public views tell us"), Riben wenti ziliao, 2, p.23.

135 Sneider, Daniel. (2013). "Textbooks and Patriotic Education: Wartime Memory Formation in China and Japan," Asia-Pacific Review, 20(1), p.41.
} 
detailed events and usage of pictures to show what happened in Nanjing at that time. Moreover, after describing this horrible event, it leaves an open discussion for students: "The rightwing of Japanese tries to deny what Japanese troops had done in the Nanjing Massacre - the ultimate act of human cruelty — during the Second SinoJapanese War. They consider it a sort of normal behaviors in wartime. What do you think of it?"136 In addition, the teacher's guide required all teachers in high schools to pay attentions to the following content:

During the War of Resistance against Japanese, Japanese aggressor troops had committed countless crimes to Chinese people, which includes slaughter, arson, looting and raping. Among all the crimes, Nanjing Massacre is the cruelest one committed by the invading Japanese troops...Apart from Nanjing Massacre, bacteriological Unit 731 of Japanese army is another one. Unit 731 had not only created biological weapons, but also conducted vivisections experiments on Chinese soldiers and civilians. ${ }^{137}$

It finally concludes that the war crimes conducted by the Japanese military can be seen as bestial crimes against humanity.

The contents of "Patriotic Education Campaign" are not limited in the process of revising the textbooks, but include various aspects: the promotion of patriotic films, the emphasis on flag-raising ceremonies, and the establishment of "Patriotic Education Bases" and museums around the country. In November 1993, the CCP Central Propaganda Department, the Ministry of Culture and the State Education Commission issued a joint document-“Circular on Carrying out Education in Patriotism in Primary and Secondary Schools throughout the Country by Films and Television". Beijing municipality soon exhibited the show of "100 patriotic education films"138 recommended by the central government. By 1994, over 95\% of primary and secondary school students in Beijing have been organized to watch those patriotic

\footnotetext{
136 Ibid. p.48

137 Zhongguo xiandailishi: jiaoshi zhidao (Modern Chinese history: a teacher's guide), (2002). Beijing: People's Education Press.

138 "Wei qingnianren tigong zuihao de jingshen shilian" ("To provide the teenagers with the best manna"), (October 1, 2004), Renminribao, p.6.
} 
films. ${ }^{139}$ In terms of the theme of these patriotic films, Gries argues that "victim narrative" had dominated a big screen. Through making a contrast of two films: Lin Zexu (1959) and Opium war (1997), both of them are about the First Opium War (1840-1842), Gries points out that the former is "a story of the Chinese people's heroic anti-imperialist struggle", while the latter reveals a "dark and depressing tragedy of the past". 140 Moreover, the flag-raising ceremony was imposed to all primary and secondary schools every Monday to promote students' patriotic sentiment. Even in Tiananmen Square, the solemn flag-raising ceremony is conducted every day keep pace of the sunrise to inspire common love of the nation.

What is more, many "Patriotic Education Bases" were established to construct young people's historical memory. The central government issued two documents respectively in 1991 and 1994 to explain the importance of using the existing historic sites and establishing new "patriotic education bases" for patriotic education. ${ }^{141}$ In 1995, the Ministry of Civil Affairs announced that there were 100 sited selected as the national-level "Patriotic Education Bases" around the whole country. It is worth noting that, among the selected 100 sites, 40 are built to memorize China's conflicts with foreign invaders, including anti-Japanese War, Korean War, Opium War so on and so forth. Among these 40 sites, 20 of them are in remembrance of the Second Sino-Japanese War. ${ }^{142}$ In fact, the two most famous memorial sites in China are all related to the Second Sino-Japanese War. The first one called Chinese People's Memorial Hall of Anti-Japanese War, which was established in 1987 and rebuilt in 1995. It is well known for an inscription written by China's former president Jiang Zemin, which reads: "Hold high the patriotic banner, use history to educate people, promote and develop Chinese national spirit and rejuvenate the Chinese nation." 143

\footnotetext{
139 Zhao, Suisheng. (1998). "A State-Led Nationalism: The Patriotic Education Campaign in Post-Tiananmen China," Communist and Post-Communist Studies, 31(3), p.292.

140 Gries, Peter H. (2005).’'Nationalism, Indignation and China's Japan Policy," SAIS Review, 25(2), p.109.

141 They were: "Notice about Conducting Education of Patriotism and Revolutionary Tradition by Exploiting Extensively Historical Relics" issued by the CCP Central Propaganda Department in 1991 and "Outline on Implementing Patriotic Education" issued by the CPC Central Committee in 1994.

142 Wang, Zheng. (2008). "National Humiliation, History Education, and the Politics of Historical Memory: Patriotic Education Campaign in China," International Studies Quarterly 52, pp.795-796.

${ }^{143}$ Ibid.
} 
The second one is Nanjing Massacre Memorial Hall, which located in the old capital of China history. Hundreds of pictures are exhibited vividly in the museum to depict the murder to 300,000 innocent citizens of Nanjing and Chinese soldiers by the Japanese army. Every year, over five million people would visit this museum to memorize the victims in the massacre. ${ }^{144}$ The message this museum intend to send is: do not forget the immoral massacre conducted by the Japanese in Nanjing. This museum mainly conveys a "victim" narrative of China under the hurt of Japanese troops, and further links it to the humiliation sentiment, indicating that China is the victim in front of both Japanese and the West.

During this "Patriotic Education Campaign", humiliation narratives have been increasingly embedded in governmental organizations, popular culture, and public media. Many governmental organizations have participated in this campaign, including CCP Central Committee, the CCP Central Propaganda Department, Ministry of Education, the State Education Commission, the Ministry of Culture, and the state-run television and radio stations. As a result, routine procedures regarding the patriotic education have been developed to administer works in these agencies. In addition, with no special case, employees of government organizations and teachers in schools were also required to have classes about patriotic education, in order to conduct the campaign efficiently. So for that, the content of this kind of patriotic campaign has penetrated to every facet of lives around Chinese people through various ways.

\section{Influence of the new wave of victim discourse on Chinese society}

It may be difficult to evaluate the influence of this "Patriotic Education Campaign" faced the whole Chinese society, but we can consult Chinese people's reactions to certain issues between China and Japan as well as the results of public surveys to take

144 Sneider, Daniel. (2013). "Textbooks and Patriotic Education: Wartime Memory Formation in China and Japan, Asia-Pacific Review," 20(1), pp.42-44. 
a glance at the real impact of this nation-led victim discourse. In the first place, Chinese people's reaction on Japanese Emperor Akihito's visit in 1992 showed that the public attitude towards Japan had already experienced a significant change. Although China Daily admitted that the emperor's visit has a positive meaning, its final conclusion was that the future of Sino-Chinese relations was still unpredictable. ${ }^{145}$ Why did not Chinese media show many expectations on this historic visit? In order to answer this question, it is important to see the public feeling towards Japan at that moment. On $9^{\text {th }}$ October 1992, few weeks before the emperor's visit, the South China Morning Post published an article about the mounting tensions between the two countries. According to this article, military, police and universities had received a secret document from the government that they have to be alert to a potential demonstration by the "Chinese Popular Committee for Japanese Reparations", members of the committee were dissatisfied with the reconciliation with Japan in Maoist period and Tanaka Kakuei's ambiguous "regret"146 to China in 1972.

The article further pointed out that these people expected the emperor to give a formal apologize for Japanese military's atrocities in the war. ${ }^{147}$ Reported by the same article, a poll conducted by Beijing Review showed that nearly $95 \%$ of the total 1,138 respondents considered that Japan own China a formal apology for its war crime, and $75 \%$ of them wanted Japanese government to pay the war reparation which had been renounced by Zhou Enlai in 1972.148 If the result of this 1992 poll is true, compared to the result of the 1989 poll in which nearly $60 \%$ Chinese respondents tended to forgive Japan's atrocities in the war, the attitude of Chinese people towards Japan and the war had changed significantly. Thus natural questions here are: why Chinese people's views on the anti-Japanese war had transformed within just three years? Why

\footnotetext{
145 China Daily Business Weekly, 1992, Quoted from: Rozman, Gilbert. (2002)." China's changing images of Japan, 1989-2001: the struggle to balance partnership and rivalry," Internal Relations of Asian-Pacific, 2(1), p.101. 146 Premier Tanaka Kakuei used the word "unfortunate period" to describe the wartime, and expressed Japan's "deep reflection" on it. Prime Minister Tanaka's speech at the welcome dinner hosted by Premier Zhou, 25 Sept. 1972, in Tian, Huan, (Ed.). (1997). Zhanhou zhongri guanxi wenxianji (Sino-Japanese relations in post-war era), Beijing: Zhongguo Shehui Kexue Chubanshe, p.105.

147 South China Morning Post, (1992, October 9), p.4, quoted in:

148 Ibid. It is also worth noticing that the Post asserted that this national poll by Beijing Review failed to publish in the end.
} 
the dissatisfaction to the 1972 renouncement of war reparation did not occur until two decades has passed, while good bilateral contact in both economic and political had already been built between the two countries? This article considers that this change was from the rising of Chinese nationalism. Chinese nationalism had been deeply influenced by the re-generation and popularity of the victim narrative which serves as the most essential content in "Patriotic Education Campaign". On 22nd June, 1989, People's Daily started to evoke "national humiliation" discourse again by asserting that "for a country, to get rid of foreign enslavement and to become independent and self-reliant are the prerequisite for its development". It also pointed out that China was utterly depending on and bullied by "others" before $1949 .{ }^{149}$ According to Suzuki, compared with other imperialist countries who had invaded China before, the aggression of the Japanese military was the most recent and bloodiest one. ${ }^{150}$ Thus, the pre-1949 national memory of the "atrocious Japanese", which had been veiled by the class-based "enemy" in Maoist era, reappeared in their mind and was magnified by the continuing "Patriotic Education Campaign".

In the second place, national polls about Chinese people's attitude towards Japan started from the early-2000s provide us a useful evidence to see what kind of role "history issue" plays to Chinese in Sino-Japanese relations at present. On the $30^{\text {th }}$ anniversary of diplomatic normalization between China and Japan in 2002, Institute of Japanese Studies restarted national polls about Japanese image and Sino-Japanese relations in China. Since 2002, this survey had been conducted in 2002, 2004, 2006 and 2008 separately to observe the change of Chinese people's attitude to Japan. ${ }^{151}$ In the first 2002 survey, when being asked the question "This year is the $30^{\text {th }}$ anniversary of the normalization of relations between China and Japan. Do you feel affinity with

\footnotetext{
149 "Zhiyou shehui zhuyi canneng jiuzhongguo" ("Only socialism can save China”), (July 22, 1989), Renminribao, p.1.

150 Suzuki, Shogo. (2007). "The Importance of 'Othering' in China's National identity: Sino-Japanese Relations as a Stage of Identity Conflicts," The Pacific Review, 20(1):23-47.

${ }^{151} \mathrm{Li}$, Chunguang, etc. (2002). "Diyici zhongri yulun diaocha" ("The first survey on public views towards SinoJapanese relations"), Japanese Studies, 6: 19-23; Ding Min, etc. (2004). "Dierci zhongri yulun diaocha" ("The second survey on public views towards Sino-Japanese relations"), Japanese Studies, 6: 33-38; Deng, Shunying, etc. (2006). "Disanci zhongri yulun diaocha" ("The third survey on public views towards Sino-Japanese relations"), Japanese Studies, 6: 27-31; Wang, Wei. (2009), "Disici zhongri yulun diaocha: peiyang jiangguo minzhong qinjin xinrengan renzhong daoyuan" ("The third survey on public views towards Sino-Japanese relations"), Japanese Studies, 2: 3-35.
} 
Japan?" only $5.9 \%$ of Chinese respondents chose the option "feel affinity" or "feel very affinity". It is worth mentioning that there were 53.6\% of Chinese respondents selected these two opinions in the 1989's survey. ${ }^{152}$ In contrast, people who do not feel affinity with Japan accounted for $43.3 \%$ of the whole respondents, and this figure kept in a high level constantly in the following three surveys with $53.6 \%$ in 2004 , $52.9 \%$ in 2006 and $58.6 \%$ in 2008 . For those who do not feel an affinity to Japan, when it comes to the reason why they feel like this, around $80 \%$ of them attributed it to the "history issue". To be more specific, over $60 \%$ participants pointed out that Japan has not reproached itself for the past aggression, and nearly $20 \%$ simply ascribed it to the war. Compared to the result of the survey in 1989 , in which only $27.5 \%$ of Chinese respondents thought that Japan had not deeply reflected on its past aggression, the "history issue" has gradually become a main concern in Chinese side. When talking about the question "what images pop out into your mind first when it comes to Japan?" the option "Japanese aggression troops" were always the first or second choice for respondents. ${ }^{153}$

Another series polls conducted jointly by the Japanese thinktank Genron NPO and China Daily in eight consecutive years since 2005 also show that Chinese attitudes towards Japan have a strong connection with the history memories. The survey shows that Chinese negative views to Japanese has increased constantly and reached the worst result in 2013 with over 92.8\% Chinese hold bad views. Asked why they hold negative views to Japan, Chinese respondents especially the students tend to give the answers like "Japanese have invaded China" and "Japanese do not properly reflect their aggression in wartime". In $2011,74.2 \%$ of general people and $71.2 \%$ students who hold negative views to Japanese because "Japan have invaded China" while this reason ranks the second in 2013 survey, in which the dispute around Diaoyu/Senkaku islands becomes the first. In addition, student respondents always give higher weight

\footnotetext{
152 Jiang, Lifeng. (1989). "Zhongri lianhe jinxing de shehui yulun diaocha shuomingle shenme" ("What can the result of the joint survey of public views tell us"), Riben wenti ziliao, 2: 22-25.

${ }^{153}$ In 2002 and 2008, "Japanese aggression troops" ranked the first with $53.5 \%$ and $67.0 \%$ of respondents' selection, while in 2004 and 2006, falling behind "Sakura", this opinion ranked the second with $40.3 \%$ and $44.5 \%$ people chose it.
} 
to the "apology issue" and believe Japan has not acknowledged what it did to China sincerely. When it comes to the question "What pop up in your mind first when you think of Japan", Nanjing Massacre always in the top two of Chinese respondents' list, and the other one is Japanese electronic goods. ${ }^{154}$ Therefore, the history issue with Japan is the main obstacle for most Chinese to see Japan. In other words, Chinese people, especially the younger generations, have been given a particular lens to see their neighbor Japan, through which China is always the victim who should fight back. In the third place, strong anti-Japanese sentiments started in the new century provide a direct example to evaluate the influence of the patriotic education on Chinese nationalism, especially the anti-Japanese nationalism. In 1996, the publication of a book named China Can Say No (Zhongguo Keyi Shuobu) ${ }^{155}$ symbolized that Chinese nationalists have already become an important power in China's society. This book sold 50,000 copies in the first two weeks and was reprinted many times to meet the public need. Finally, it sold as many as 3 million copies in China. The popularity of China Can Say No symbolized Chinese nationalism's upsurge since the middle-1990s. If we considered the second half of 1990s was full of anti-Western, especially antiUS sentiments, for example, the massive anti-US demonstrations in 1999 because of the bombing of Chinese embassy in Belgrade, then the theme of the post-2000 era Chinese nationalism is abomination towards the Japanese. If we look back on the antiJapanese sentiment in Sino-Japan relations' history, it is clear that the protests and demonstrations against Japan in China appear much more frequently since the $21^{\text {st }}$ century.

Early in 2003, the territorial dispute on Diaoyu/Senkaku Island has already been put on the table. The Japanese government leased three of the five islands of Diaoyu/Senkaku Island group from a private family; this action has irritated Beijing

\footnotetext{
154 Polling data from 2011 to 2013. Retrieved on October 10, 2013, are available on the China Daily website at: http://www.chinadaily.com.cn/hqjs/2011-08/04/content_13092005.htm; http://www.chinadaily.com.cn/hqzx/2012-06/19/content_15512904.htm; http://www.chinadaily.com.cn/hqzx/2013-08/05/content_16872036.htm;

155 Song, Qiang \& Qiao, Bian. (1996). "Zhongguo keyi shuobu: lengzhanhou shidai de zhengzhi yu qinggan xuanze" ("China can say no: political and emotional choices in the post Cold-war era"), Beijing: Zhongguo Gongshang Lianhe Chubanshe.
} 
and Chinese public. The event has caused a tremendous nationalism in China in the next few months and reached a peak in June 2003.156 In August, 2003, there was an online petition organized by Chinese netizen to call on the Chinese government not to sign a $\$ 12$ billion contract of the Beijing-Shanghai high-speed railway with Japan. By drawing parallels with the Manchurian railway that Japan built in the 1920s, protesters in China considered the new railway construction as a "re-invading" by Japan. ${ }^{157}$ The online petition has collected over 90,000 signatures within one week. It is worth noticing that an aggressive slogan was showed on the front page of their website: "Heaven and Earth will not tolerate traitor. We refuse the use of Japanese products for the Beijing-Shanghai line". ${ }^{158}$ In the context of this slogan, if the government finally agreed to sign this contract with the Japanese, it will become a national "traitor" who chose to stand with the "enemy"-Japan. This "our/others" line drew by the public forced Chinese government to postpone the high-speed railway contract with Japan. Then, on $4^{\text {th }}$ August, the "Gas Incident" in the city Qiqihar incurred a quick and furious reaction from the public. Over a million Chinese people have signed on a petition, which demanded Japanese to resolve the chemical weapons problem. ${ }^{159}$ On September $18^{\text {th }}, 2003$, Chinese nationalists quickly transferred their attention to another incident - a sex party held by Japanese businessmen in southeast China. It stirred another anti-Japanese sentiment online. In October 2003, the Japanese-style skit performed by Japanese students in North-western University provoked an anti-Japanese demonstration of 7,000 people. In the year 2003, Chinese people's abomination towards the Japanese has been growing without any stop.

Anti-Japanese sentiment went on in 2004 and 2005. During the Asian Cup soccer tournament in August 2004, Chinese soccer fans in many cities insulted Japanese players orally by shouting "Sha, Sha, Sha" (Kill, Kill, Kill), and "Dadao Xiang

\footnotetext{
156 Gries, Peter H. (2005). “China's "New Thinking” on Japan,” The China Quarterly,184, PP.844-846.

157 Reilly, James. (2011). "Remember History, Not Hatred: Collective Remembrance of China's War of Resistance to Japan," Modern Asian Studies, 45(2), P.475.

158 Ibid.

159 Ibid.
} 
Guizimen de Toushang Kanqu" (a big sword decapitate the Japanese devil). ${ }^{160}$ In 2005, the history textbook event and Japan's bid for permanent membership on the UNSC have triggered another wave of anti-Japanese emotion in China. As for the former event, in April, a new edition of junior high school history textbook which had sparked a tremendous dissatisfaction in China was approved by the Japanese Ministry of Education after 4 years. This "provocative" action of Japanese government resulted in massive anti-Japanese street protests in many Chinese cities. In Beijing, participants smashed hundreds of electronic devices that sold in a technology hub during the demonstration. In the spring of 2005, nearly 19 million of Chinese people have signed on an online petition in order to against Japan's bid for permanent membership of the UNSC. Apart from the petition, tens of thousands of people took to streets, andtjose extreme protesters even damaged Japanese shops and offices, overturned and torched Japanese-brand cars, and threw eggs at the Japanese embassy and the ambassador's official residence. ${ }^{161}$

All in all, the patriotic campaign have got a success in stimulating public resonance, and Japan severed as a primary "others" of China. For Chinese nationalists, Japan has become China's ultimate "enemy". Any actions against it should be considered as a true patriot. As Geremie Barmé says, "Patriotic sentiment is no longer the sole province of the Party and its propagandists."162 From this point, Chinese nationalists have gradually growing beyond the government expectation, and the massive antiJapanese throughout the whole country since the 2000s should be seen as a good example.

\footnotetext{
160 Yardley, Jim. (August 9, 2004). "In soccer loss, a glimpse of China's rising ire at Japan," New York Times. Retrieved on October 23, 2013, from: http://www.nytimes.com/2004/08/09/international/asia/09china.html 161 Kang, Su-Jeong. (2013). “Anti-Japanese Popular Nationalism and China’s Approach Towards Japan amid Sino-Japanese Political Tension, 2001-2006," East Asia, 30, p.165.

162 Barmé, Geremie. (1995). "To Screw Foreigners Is Patriotic: China's Avant-Garde Nationalism," The China Journal, 34, pp.211-212.
} 


\section{Conclusion}

The sense of national humiliation of Chinese people derives from a huge psychological gap between an Empire and a peripheral nation-state which invaded by foreign imperialists in the $19^{\text {th }}$ century and early $20^{\text {th }}$ century. Base on the glorious 5,000 -year civilization in the past, history of being invaded by the foreigners makes the Chinese feel difficult to accept, and the gap between the past prosperity and what happened in contemporary society let Chinese people tend to define the latter as a "national humiliation". In the "Century" Chinese people did suffer a lot, and the memories of the wartime have deeply rooted in Chinese people's mind. However, direct war experience and the meaning attached it are not the same. Apart from history itself, the narrative of history is significant in constructing a nation's identity. Besides, this "national humiliation" myth determines the way how Chinese deal with the Western and its immediate neighbor-Japan. Looking back on the humiliation narrative in different periods since 1915, this thesis contends that China's humiliation discourse is an integral part of the shaping of national identity and Japan plays an important role in it.

In the first place, it concludes that the ruling governments play an indispensable role in using the humiliation narrative to shape China's national identity. As John Gills argues, "[T]he core meaning of any individual or group identity...is sustained by remembering; and what is remembered is defined by the assumed identity." 163 This thesis believes that Chinese political elites, particularly, the ruling governments determine the "assumed identity". They play an essential role in shaping the nation's identity by embedding certain narratives into the public's mind.

The narrative of the national past helps construct China's identities in different periods with different meanings. The discourse of the "Century of National Humiliation" first emerged in January 1915 when Japanese imperialist impose the

\footnotetext{
163 Gillis, John R. (1996). Commemorations: The Politics of National Identity, Princeton: Princeton University Press, p.5
} 
unequal treaty_-“Twenty-one Demand” on Chinese Beiyang government (1912-1927), which seriously violated Chinese national sovereignty. Soon after Yuan Shikai's sign of the "Twenty-one Demand" with Japan on May 9" 1915 , the public tended to mark this event as a national humiliation. During this short period, social power played more active roles in popularizing the national humiliation narrative than government in mobilizing Chinese people. When the Kuomin Party (KMT) took over the office in the late 1920s, national humiliation discourse had gradually served as a government instrumental tool to construct a uniform national identity. Different from Beiyang era, the KMT government played a more active role in popularizing the discourse of national humiliation. It inherited the humiliation narrative and then summarized all those previous national humiliation days into an official calendar, and reset them in a legal way. In other words, the KTM authority had become the only legal actor to control the myth of "national humiliation". All in all, the victim narrative was a dominant theme in the pre-1949 era. From 1949 to the end of 1980s, victim narrative had totally disappeared in Chinese civil society. From Mao's perspective, China was a "victor" rather than a "victim". The assertion that CCP's role was the main cause of Japan's surrender had dominated the whole country. While between the late-1970s and the late-1980s, neither "victor narrative" nor "victim narrative" were used by the government to construct a national identity. Based on the "reform and opening up" policy, Chinese government has gradually changed from an idealist to a pragmatist who put top priority on the development of the domestic economy. Yet, when the spring of 1989 came, everything was changed. The 1989 Tiananmen Incident made the party leader Deng Xiaoping to reflect on his previous strategy, and decided to attach more importance on ideological education to maintain the communist regime. Therefore, soon after 1989, the "Patriotic Education Campaign" was launched by the Party, and the "Century of National Humiliation" discourse thus was rediscovered by the government to legitimize its rule and help to overcome the regime crises.

In the second place, this thesis concludes that Japan plays an important role in the construction of China's national identity. More specifically, Chinese people's hostility 
towards Japan is rooted in the evolution of the national humiliation discourses. Over the pre-1949 era, when the Beiyang government signed the "Twenty-One Demand" with Japan, the latter had first become an immoral "other" for China's national humiliation discourses. The popularization of the narrative of national humiliation gave an upsurge of Chinese people's anti-Japanese sentiments. Japan became China's major "enemy" at that time. Later, the KMT government further constructed Japan as a "national enemy" to motivate the population to prepare for the upcoming war. During this time, Japan's increasingly deepening important role in Chinese humiliation myth was reflected not only by the establishment and the practice of the "National Humiliation Days", but also through the official propaganda goals which was characterized by anti-Japanese discourses. After CCP's come to power in 1949, the official emphasis on "atrocious Japan" disappeared in accordance with the absence of victim narrative from Chinese society during Mao's era. Being conscious of great threats from the KMT-led regime and its US ally, communist government determined to anchor new Chinese national identity of communist ideology and intended to draw Japan into its Communist Camp. In this sense, the mass good Japanese people were separated from those few bad militarists and considered as Chinese people's "friends". After Maoist era, Japan was neither a friend nor a foe but an important cooperative partner for China. Since the government's pragmatic approach towards Japan, the Sino-Japanese relationship reached a peak in 1980s in both official level and public level. "Bad" history between China and Japan seemed to be no longer an obstacle of the future Sino-Japanese relation in this period. Yet, when the spring of 1989 came, everything changed. Japan regained its character as a typical "other" through the "Patriotic Education Campaign". Although the initial objective of this "Patriotic Education Campaign" is to regain CCP's moral legitimacy, Japan has been constructed as a typical "other" to attain this goal by inspiring Chinese people's patriotism. As a result, a "devil" Japan - a country who has invaded China, killed innocent Chinese without guilty, and even try to remove it from history- has gradually come into Chinese people's mind again. 
After examining the period from 1915 to the new century, it is clear that there is no certain consistency in the interpretations of the humiliation throughout the last 100 years in China. The national humiliation discourse had once disappeared in China from 1950 s to 1980 s. However, whether humiliation discourse dominants civil society or not, the ruling governments always play an essential role in shaping the nation's identity by embedding certain narratives into the public's mind. Besides, in this process of the construction of China's national identity, Japan has been an indispensable "other". Since humiliation "is one of the modes used to draw ethical boundaries between self and other, between domestic and foreign", ${ }^{164}$ the popularization and intensification of humiliation discourse in China were always associated with anti-Japanese sentiments. As a consequence, in Chinese context, Japan always assumes the role as an "enemy" when the humiliation/victim narrative dominates the civil society. In other words, Japan's role as an immoral “other” will intensify China's self identity as a victim.

164 Callahan, William (2004). "National Insecurities: Humiliation, Salvation and Chinese Nationalism," Alternatives: Global, Local, Political, 29(2), p. 203. 


\section{References}

• “ "Aiguo zhuyi jiaoyu shishi gangyao" ("Outline on Implementing Patriotic Education"), Ministry of Education of the People's Republic of China, Red.net, 2008. Retrieved on October 2, 2013, from:

http://hn.rednet.cn/c/2008/06/30/1539945.htm.

- Barmé, Geremie. (1995). “To Screw Foreigners Is Patriotic: China’s Avant-Garde Nationalism," The China Journal, 34: 209-234.

- Bukh, Alexander. (2007). “Japan's History Textbooks Debate: National Identity in Narratives of Victimhood and Victimization," Asian Survey, 47(5): 683-704.

- Buzan, Barry. (2010). “China in International Society: Is 'Peaceful Rise' Possible?" The Chinese Journal of International Politics, 3: 5-36.

- Cai, Jane. (September 1, 2004), "Patriots' website closed because of railway protest; anti-Japan stance over bullet-train bids too sensitive for authorities," South China Morning Post. Retrieved on October 23, 2013, from: http://www.scmp.com/article/468585/patriots-website-closed-because-railwayprotest.

- Callahan, William A. (2004). "National Insecurities: Humiliation, Salvation and Chinese Nationalism,” Alternatives: Global, Local, Political29(2): 199-218.

- Callahan, William A. (2006). "History, identity, and security: Producing and consuming nationalism in China," Critical Asian Studies, 38(2): 179-208.

- Campbell, David. (1998). National Deconstruction: Violence, Identity, and Justice in Bosnia, Minneapolis: University of Minnesota Press.

- "Canbai jingguo shenshe de lidai riben shouxiang" ("Japanese premiers' worship at Yasukuni Shrine in the past"), Hexun News. Retrieved on November 20, 2013, from: http://news.hexun.com/2013-12-27/160969655.html.

- Chang, Iris. (1997). The rape of Nanking: the forgotten holocaust of World War II. New York: Basic Books. 
- Chen, Jie. (1995). "The Impact of Reform on the Party and Ideology in China," Journal of Contemporary China, 9: 22-34.

- Chen, Jin (1997), “Mao Zedong yu Jingju Gaige" ("Mao Zengdong and Peking Opera Revolution”), Dangshi tiandi, 6: 21-25.

- Cheng, Yongming \& Shi, Baoqi. (2005). Zhongri Jingmao Guanxi Liushinian (Sino-Japanese Economic and Trade relations in 60 Years), Tianjin: Tianjin sehui kexueyuan Chubanshe.

- China Daily, public opinions surveys from 2011 to 2013:

"2011 Zhongri guanxi yulun diaocha baogao" ("Report of public opinions on Sino-Japanese relations, 2011 ”). Retrieved on October 17, 2013, from:

http://www.chinadaily.com.cn/hqjs/2011-08/04/content_13092005.htm;

“2012 Zhongri guanxi yulun diaocha baogao" ("Report of public opinions on Sino-Japanese relations, 2012”). Retrieved on October 17, 2013, from:

http://www.chinadaily.com.cn/hqzx/2012-06/19/content_15512904.htm;

“2013 Zhongri guanxi yulun diaocha baogao" ("Report of public opinions on Sino-Japanese relations, 2013”). Retrieved on October 17, 2013, from: http://www.chinadaily.com.cn/hqzx/2013-08/05/content_16872036.htm.

- Clark, Paul. (2008). The Chinese Cultural Revolution: A History. Cambridge; New York: Cambridge University Press.

- Coble, Parks M. (2007). "China's "New Remembering" of the Anti-Japanese War of Resistance," 1937-1945, The China Quarterly, 190: 394-410.

- Cohen, Paul A. (2002). "Remembering and Forgetting: National Humiliation in Twentieth-Century China," Twentieth-Century China, 27(2): 1-39.

- Deng Xiaoping Sixiang Nianpu, 1975-1997, (Annals of Deng Xiaoping's Thoughts, 1975-1997), Beingjing: Zhongyang wenxian Chubanshe. 
- $\quad$ Deng Xiaoping wenxuan disanjuan (Deng Xiaoping, selected works Vol. 3)

"Zaijiejian shoudu jieyan budui junyishang ganbushi de jianghua" ("Address to

officers at the rank of general and above in command of the troops enforcing martial law in Beijing”), speech of 9 June 1989. Retrieved on October2, 2013, from:http://www.china.com.cn/zhuanti2005/txt/2004-08/02/content_5625194.htm

- Deng Xiaoping wenxuan diyijuan (Deng Xiaoping, selected works Vol.1), "Zenme huifu nongye shenchan" ("How to restore agricultural production"), speech of 7 July 1962. Retrieved on December 5, 2013, from: http://news.xinhuanet.com/2011-04/24/c_121341795.htm.

- Deng Xiaoping Xuexi Gangyao (Study Outline of Deng Xiaoping's Diplomatic Thoughts), Beijing: Xinshijie Chubanshe.

- Deng, Shunying, etc. (2006). "Disanci zhongri yulun diaocha" ("The third survey on public views towards Sino-Japanese relations"), Japanese Studies, 6: 27-31.

- Ding, Min, etc. (2004). "Dierci zhongri yulun diaocha" ("The second survey on public views towards Sino-Japanese relations"), Japanese Studies, 6: 33-38.

- Gillis, John R. (1996). Commemorations: The Politics of National Identity, Princeton: Princeton University Press.

- Gong, Gerrit W. (1984). The Standard of Civilization in International Society, Oxford: Clarendon Press.

- Gries, Peter H. (2005). “A Preliminary Analysis of Chinese Nationalism: The People, Their Pasts, and Their Passions," World Economics and Politics, 11: 4248.

- Gries, Peter H. (2005). “China's 'New Thinking' on Japan,” The China Quarterly, 184: 831-850.

- $\quad$ Gries, Peter H. (2005). “Nationalism, Indignation and China’s Japan Policy,” SAIS Review, 25(02): 105-114.

- Gu, Lvtong. (1933). Guochi jinianshi (History of the Memorial of National Humiliation), Shanghai: Xinzhongguo Chubanshe. 
• “Guojia jiaowei 1991 nian gongzuoyoadian” ("General Outline on Strengthening Education on Chinese Modern and Contemporary History and National Conditions"). Retrieved on October 2, 2013, from:

http://www.moe.edu.cn/publicfiles/business/htmlfiles/moe/moe_164/200408/344 0.html.

- He, Yinan. (2007). "Remembering and Forgetting the War: Elite Mythmaking, Mass Reaction, and Sino-Japanese Relations, 1950-2006," History and Memory, 19(02): 43-74.

- Huang, Dahui. (2008). "Zhongguo gaige kaifang sanshinian yu zhongri guanxi" (“30 years of development in Sino-Japanese relations”), Jiaoxueyu yanjiu, 11: 1620.

- Huang, Zemin. (1997). "Xunsu fazhan de zhongri maoyi guanxi” ("rapid development of Sino-Japanese trade relations”), International Survey, 4: 11-14.

- Hughes, Christopher R. (2006), Chinese Nationalism in the Global Era, NewYork: Routledge.

- Jiang, Lifeng. (1989), “Zhongri lianhe jinxing de shehui yulun diaocha shuomingle shenme" ("What can the result of the joint survey of public views tell us"), Riben wenti ziliao, 2: 22-25.

- Jianguo yilai Mao Zedong wengao, di shisance (The manuscripts of Mao Zedong since the Founding of the Nation, no.13), Beijing: Zhongyang Wenxian Chubanshe.

- Kahn, Joseph. (September 30, 2003), “China angered by reported orgy involving Japanese tourists," New York Times, p.A5. Retrieved on October 23, 2013, from: http://www.nytimes.com/2003/09/30/world/china-angered-by-reported-orgyinvolving-japanese-tourists.html.

- Kang, Su-Jeong. (2013). “Anti-Japanese Popular Nationalism and China’s Approach Towards Japan amid Sino-Japanese Political Tension, 2001-2006,” East Asia, 30: 161-181. 
- Li, Chunguang, etc. (2002). "Diyici zhongri yulun diaocha" ("The first survey on public views towards Sino-Japanese relations"), Japanese Studies, 6: 19-23.

- Lian, Xinbian. (1966). Guochi shiyao (Brief history of national humiliation). She, Yunlong (Ed.), Jindai Zhongguo Shiliao Congji, vol.90. Taipei: Wenhai Chubanshe.

- Lin, Delian. (1990). DangdaiZhongriGuanxishi (Contemporary relations between China and Japan), Beijing: Zhongguo duiwai jingjimaoyi Chubanshe.

- $\quad$ Liu, Yingjie. (Ed.) (2001). Zhongguo jiaoyu dashidian (1840-1949). Hangzhou: Zhejiang jiaoyu Chubanshe.

- $\quad$ Mao Tse-tung. (1954). The Policies, Measures, and Perspectives of Combating Japanese Invasion, Beijing: Foreign Languages Press, pp. i-ii.

- $\quad$ Mehlinger, Howard D. (1985). "International Textbook Revision: Examples From the United States," Internationale Schulbuchforschung, No.7.

- Mitter, Rana. (2000). "Behind the Scenes at the Museum: Nationalism, History and Memory in the Beijing War of Resistance Museum, 1987-1997," The China Quarterly 161(1), 279-293.

- $\quad$ Moore, Gregory J. (2010). "History, Nationalism and Face in Sino-Japanese Relations," Journal of Chinese Political Science, 15: 283-306.

- $\quad$ Podeh, Elie. (2000). "History and Memory in the Israeli Educational System: The Portrayal of the Arab-Israeli Conflict in History Textbooks (1948-2000)," History and Memory 12 (1): 65-100.

- Postgraduate BBS of JiLin University. Retrieved on December 2 2013, from: http://bbs.jlu.edu.cn/cgibin/bbsanc?path=/groups/GROUP_1/Postgraduate/D8181B436/D8C6D3F95/D85 DE5B31/M.1067686766.A

- Reilly, James. (2011). "Remember History, Not Hatred: Collective Remembrance of China's War of Resistance to Japan," Modern Asian Studies, 45(2): 463-490. 
- Renminribao (July 22, 1989), "Zhiyou Shehuizhuyi Canneng Jiuzhongguo" (“Only Socialism Can Save China"), p.1.

- $\quad$ Renminribao (October 1, 2004), “Wei qingnianren tigong zuihao de jingshen shiliang" ("To provide the teenagers with the best manna"), p.6.

- " 'Renminwang Yuqing Jianceshi Fabu '2012nian zhongguo hulianwang yuqing fenxi baogao" ("People.com public opinion inspection office published '2012 Report of China Internet Public Opinion Analysis"'), (2012, November 21), People.com. Retrieved October 20, 2013, from: http://yuqing.people.com.cn/n/2012/1221/c210123-19974822.html.

- $\quad$ Rose, Caroline. (1998). Interpreting History in Sino-Japanese Relations: A Case Study in Political Decision-Making, New York: Routledge.

- Rozman, Gilbert. (2002). “China’s changing images of Japan, 1989-2001: the struggle to balance partnership and rivalry," Internal Relations of Asian-Pacific, 2(1): 95-129.

- Shenbao (1922, May 8). "Shandonglu shanglianhui zhi wujiuchi” ("May 9 humiliation of Shangdong Road commercial chamber").

- $\quad$ Shenbao (1927, May 10), “Zuori wujiu guochi jinian dahui" ("Yesterday’s May 9" memorial conference"), p.13.

• Shenbao (1928, May 9). "Yongyuan buwang: guochi jinian xiaoshuo" ("Never forget: a national humiliation commemorative story").

- Shenbao (1929, May 10). "Zhongshuju xing wujiu guochi jinian" ("Central bureau held May 9 national humiliation day memorial"), p.6.

- Shenbao (1933, May 9). “Jinri wujiu guochi jinian" ("Recent May 9 national humiliation memorials"), p.8.

- Shenbao (1934, May 10). "Gejie daibiao zuori juxing wujiu guochi jinian dahui” ("Delegates from all circles held May 9 national humiliation memorials yesterday"), p. 10 . 
- Shenbao (1940, May 7) "Zhongyang feichu wujiu jinian” ("Central government cancels May $9^{\text {th }}$ commemoration") 7 May, p.4.

- $\quad$ Sneider, Daniel (2013). “Textbooks and Patriotic Education: Wartime Memory Formation in China and Japan," Asia-Pacific Review 20(1): 35-54.

- $\quad$ Song, Qiang \& Qiao, Bian. (1996). Zhongguo keyi shuobu: lengzhanhou shidai de zhengzhi yu qinggan xuanze (China can say no: Political and Emotional Choices in the post Cold-War era), Beijing: Zhongguo Gongshang Lianhe Chubanshe.

- Suzuki, Shogo. (2007). “The Importance of 'Othering' in China's National identity: Sino-Japanese Relations as a Stage of Identity Conflicts," The Pacific Review 20(1): 23-47.

- Wang, Jisi. (1994). "International Relations Theory and the Study of Chinese Foreign Policy: A Chinese Perspective," in Thomas Robinson and David Shambaugh (Eds.), Chinese Foreign Policy: Theory and Practice, New York: Oxford University Press.

- Wang, Quanbao. (May 5, 2008). “Jiyi 1984: zhongri qingnian Tiananmen gongwu de rizi" ("Remembrance 1984: the days of Chinese and Japanese youth dancing together in Tiananmen"), Dongfang Zaobao. Retrieved on December 3, 2013 from: http://epaper.dfdaily.com/dfzb/html/2008-05/05/content_54929.htm.

- Wang, Wei. (2009), "Disici zhongri yulun diaocha: peiyang liangguo minzhong qinjin xinrengan renzhong daoyuan" ("The third survey on public views towards Sino-Japanese relations"), Japanese Studies, 2: 3-35.

- Wang, Zheng. (2008). "National Humiliation, History Education, and the Politics of Historical Memory: Patriotic Education Campaign in China," International Studies Quarterly, 52: 783-806.

- White, Tyrene. (1990). "Post revolutionary Mobilization in China: The OneChild Policy Reconsidered," World Politics, 43(1): 53-76. 
- Whiting, Allen S. (1995). “Chinese Nationalism and Foreign Policy after Deng," The China Quarterly, 142: 295-316.

• “Women you Zuiyouxiu de Rennao" ("We have the most brilliant brain”), (1997), Beijing Youth Weekly, 98: 30.

- Wu, Hung. (1998). "Ruins, Fragmentation, and the Chinese Modern/Postmodern," in Gao, Minglu, (Ed.), Inside Out: New Chinese Art, San Francisco: San Francisco Museum of Modern Art.

- "Xi'an kangri shiwei yuyan yulie" (Xi'an anti-Japanese demonstrations get fiercer and fiercer), Sing Pao Daily, (November 1, 2003). Retrieved on October 23, 2013, from: http://www.singpao.com/20031101/international/470627.html.

• Xiao, Yong. (1992). "Riben de jingyan yu zhongguo de gaige" ("Japan’s experience and China's reform"), Japanese Studies, 5: 110-126.

- "Xibei daxue fasheng xuesheng kangy iriben liuxuesheng xialiu biaoyan shijia" ("Students of North-western University protested Japanese students' 'dirty' performance”), Shouhu News, (October 31, 2003). Retrieved on October 2, 2013, from: http://news.sohu.com/89/04/news215030489.shtml.

- Yardley, Jim. (August 9, 2004). “In soccer loss, a glimpse of China's rising ire at Japan," New York Times. Retrieved on October 23, 2013, from: http://www.nytimes.com/2004/08/09/international/asia/09china.html

- Yi, Yin. (1915). Wujiu guochishi (History of May 9 Humiliation). Shanghai: Guowen Shuju.

- Yuan, Jingdong. (2008). "Chinese Nationalism and Sino-Japan Relations," Pacific Focus, 23(2): 212-231.

- Zhang, Tiejun. (2004). "Self-Identity Construction of the Present China," Comparative Strategy, 23(3): 281-301.

- Zhang, Yan \& Sun, Yanjing (Ed.), (2009). Minguo shiliao congkan, Zhengzhou: Daxiang Chubanshe. 
- Zhang, Yongjin. (2001). "System, empire and state in Chinese international relations," Review of International Studies, 27(05): 43-63.

- Zhao, Suisheng. (1998). “A State-Led Nationalism: The Patriotic Education Campaign in Post-Tiananmen China," Communist and Post-Communist Studies, 31(3): 287-302.

- Zhao, Suisheng. (2005). “China’s Pragmatic Nationalism: Is it Manageable?” The Washington Quarterly, 29(1): 131-144;

- Zhong, Zhicheng. (2006). Weile shijie gengmeihao: Jiang Zemin chufang shiji (Aiming at a more beautiful world), Beijing: Shijie Zhishi Chubanshe.

- Zhongguo xiandai lishi: jiaoshi zhidao (Modern Chinese history: a teacher's guide), (2002). Beijing: People's Education Press.

- "Zhonghua renmin gongheguo he riben zhengfu weicujin wenhua jiaoliu de xieding" ("Agreements between China and Japan to promote Cultural Exchanges"). Retried on December 2, 2013, from: http://news.xinhuanet.com/ziliao/2002-03/26/content_331611.htm.

- Zhongyang Ribao (Central Daily News), (May 7, 1928). "Guochi jinian" (“Memorial of national humiliation"), p.3.

- Zhongyang Ribao (Central Daily News), (May 10,1932). "Shoudu gejie zuori juxing guochi jinian dahul" ("Figures from all circles held national humiliation memorials in capital city yesterday"), p.3.

- $\quad$ Zhou Enlai junshi wenxuan disijuan (Zhou Enlai military thinking anthology Vol.4), Beijing: Remin Chubanshe. Retrieved on November 25, 2013, from: http://www.xiexingcun.com/zhouenlai/1-zeljswx599.htm.

- Zhou Enlai nianpu 1954 (Annals of Zhou Enlai 1954). Retrieved on November 25, 2013, from: http://www.eywedu.org/zhouenlai13/054.htm. 